\title{
Opieka pielęgniarska nad pacjentem z niewydolnością wątroby przeszczepionej, niezakwalifikowanym do retransplantacji - studium przypadku w oparciu o klasyfikację ICNP $®$
}

\author{
Nursing care of patient with liver transplant failure who was \\ disqualified from retransplantation surgery - a case study \\ based on ICNP®
}

\author{
ALEKSANDRA OSTROWSKA ${ }^{1}$, NATALIA SAK-DANKOSKY ${ }^{1}$, BOŻENA \\ CZARKOWSKA-PĄCZEK ${ }^{1}$
}

${ }^{1}$ Zakład Pielęgniarstwa Klinicznego, Wydział Nauki o Zdrowiu, Warszawski Uniwersytet
Medyczny

DOI: https://dx.doi.org/10.21784/IwP.2019.023

ISSN: 2451-1846

\section{Streszczenie:}

Wstęp. Życie pacjenta $\mathrm{z}$ niewydolnością wątroby $\mathrm{w}$ zaawansowanym stadium można uratować jedynie dzięki transplantacji. Istnieje jednak wiele przyczyn, z powodu których pacjenci mogą zostać do niej niezakwalifikowani. Opieka nad pacjentem, niezakwalifikowanym do transplantacji, wymaga szczególnego zaangażowania pielęgniarki we wszystkie biopsychospołeczne sfery życia pacjenta.

Cel pracy. Celem pracy była identyfikacja problemów pielęgnacyjnych, określenie deficytu samoopieki oraz zaplanowanie opieki pielęgniarskiej nad pacjentem z niewydolnością wątroby przeszczepionej, 
niezakwalifikowanego do retransplantacji, przebywającego $\mathrm{w}$ szpitalu na oddziale transplantologii.

Opis przypadku. Zaplanowano opiekę nad chorym $\mathrm{z}$ niewydolnością wątroby przeszczepionej w przebiegu przewlekłego odrzucania, chorującym także na przewlekłą chorobą nerek o niejasnej etiologii, u którego występują również zaburzenia świadomości, agresja, obniżony nastrój i strach przed śmiercią. W planowaniu opieki zastosowano Międzynarodową Klasyfikację Praktyki Pielęgniarskiej ICNP®.

Dyskusja. Plan opieki został opracowany według teorii Virginii Henderson. Pacjent wymagał pomocy w czynnościach dnia codziennego oraz wsparcia psychicznego, szczególnie pomocy w zrozumieniu jego obecnej sytuacji i radzeniu sobie z uczuciem samotności.

Wnioski. Zastosowanie Międzynarodowej Klasyfikacji Praktyki Pielęgniarskiej ICNP® w planowaniu opieki pielęgniarskiej nad pacjentem z niewydolnością wątroby przeszczepionej pozwala na polepszenie jakości opieki na pacjentem i umożliwiona analizę wiedzy o opiece nad pacjentem $\mathrm{w}$ kontekście międzynarodowym.

Słowa kluczowe: ICNP, ostra niewydolność wątroby, pielęgniarstwo transplantologiczne, proces pielęgnowania, przeszczepienie wątroby, transplantologia

\section{Abstract:}

Introduction. Life of patient suffering from an advanced-stage liver failure can be saved only by transplantation surgery. Many patients, however, do not qualify for this type of treatment for a variety of reasons. Caring for a patient who was disqualified from the surgery is challenging and requires focusing on all biopsychosocial aspects of patient's life.

Aim of the study. The aims of this study were to identify nursing problems, to estimate the self-care deficits, and to plan nursing care for a patient with a liver transplant failure currently hospitalized in a transplantology unit.

Case study. Nursing care of patient with a liver graft failure in the course of chronic graft rejection was carefully planned. The patient was also diagnosed with a chronic kidney disease of unknown aetiology. Moreover, the patient 
suffered from a fluctuating consciousness and mood depression, manifest aggressive behaviours and the fear of death. To plan patient's care the International Classification for Nursing Practice ICNP® was used.

Discussion. Nursing care was planned in accordance with Virginia Henderson's theory which emphasizes the Maslow hierarchy of needs Patient required help with daily activities and needed psychological support, especially in coping with his current situation and dealing with the feeling of loneliness.

Conclusions. Applying the International Classification for Nursing Practice ICNP $®$ in the planning of nursing care for a patient with liver graft failure enables the improvement of the patient's quality of life and the awareness of nursing care in the international area.

Keywords: acute liver failure, ICNP, liver transplantation, nursing process, transplant nursing, transplantology

\section{Wstęp}

Leczeniem z wyboru w przypadku pacjentów ze schyłkową niewydolnością wątroby jest transplantacja tego narządu. W ciągu ostatniego stulecia nastąpił przełomowy postęp medycyny w zakresie transplantologii. Transplantologia rozwinęła się $\mathrm{z}$ metod eksperymentalnych z wysoką śmiertelnością do niemal rutynowej procedury z coraz lepszą przeżywalnością krótko- i długoterminową $[1,2]$. Pierwsze udane przeszczepienie wątroby zostało przeprowadzone przez prof. Thomasa Starlza z zespołem w 1967r., Od tego czasu dziedzina ta zaczęła się rozwijać i liczba i jakość przeszczepień zaczęła rosnąć w coraz szybszym tempie, zapewniając poprawę zdrowia i jakości życia osób z niewydolnością wątroby [2].

Przeszczepienie jest jedynym sposobem na poprawę stanu zdrowia pacjentów z niewydolnością wątroby, dlatego po zabiegu istotne jest stosowanie się do zaleceń potransplantacyjnych, między innymi przyjmowanie leków immunosupresyjnych. Zapewnia to przeżycie zarówno narządu przeszczepionego jak i pacjenta. 
Niestety, pacjenci nie zawsze stosują się do tych zaleceń, co może skutkować konsekwencjami np. w postaci odrzucania i niewydolności przeszczepionego narządu. Pokazuje to, jak ważna jest profilaktyka i stosowanie się do porad personelu medycznego [4]. Gdy pacjent niestosuje się do zaleceń personelu medycznego, może on zostać niezakwalifikowany do ponownej transplantacji [4]. W takim wypadku znaczącą rolą personelu pielęgniarskiego jest wsparcie psychiczne chorego oraz pomoc $\mathrm{w}$ zrozumieniu sytuacji, w której pacjent się znajduje oraz staranie się o poprawę jakość jego życia.

Personel pielęgniarski, spędza z pacjentem najwięcej czasu, przede wszystkim obserwując go i jego zachowania, aby jak najlepiej zobrazować problemy pielęgnacyjne i postawić trafne diagnozy pielęgniarskie, które są następnie realizowane. Ponadto monitoruje parametry życiowe chorego, ocenia stopień nasilenia bólu oraz poziom samodzielności pacjenta. Podaje leki przeciwbólowe zgodnie ze zleceniem lekarskim i ocenia w jakim stopniu wpływają one na poprawę samopoczucia chorego. Co więcej, stanowi także wsparcie emocjonalne dla pacjenta i jego rodziny, oraz pomaga pogodzić się ze stanem zdrowia pacjenta [5,6,7].

\section{Cel}

Celem tej pracy była analiza przypadku pacjentem z niewydolnością wątroby przeszczepionej, niezakwalifikowanego do retransplantacji; identyfikacja problemów pielęgnacyjnych; określenie deficytu samoopieki; oraz zaplanowanie opieki pielęgniarskiej. W zaplanowaniu opieki nad pacjentem posłużono się Międzynarodową Klasyfikacja Praktyki Pielęgniarskiej ICNP ®, która jest uznanym międzynarodowym standardem dla terminologii pielęgniarstwa oraz integralną częścią infrastruktury informacyjnej opieki zdrowotnej. [8] 


\section{Prezentacja przypadku}

Czterdziestopięcioletni pacjent został przyjęty do Kliniki Immunologii i Transplantologii i Chorób Zewnętrznych WUM w celu diagnostyki i leczenia niewydolności wątroby przeszczepionej. Przeszczepienie wątroby choremu od dawcy zmarłego miało miejsce w 2005r. i było konieczne z powodu niewydolności wątroby własnej w przebiegu jej autoimmunologicznego zapalenia. Pacjent ma ponadto zdiagnozowaną przewlekłą chorobą nerek o niejasnej etiologii. W wywiadzie pacjent neguje przyjmowanie leków immunosupresyjnych, w związku z czym został on zdyskwalifikowany z ponownego przeszczepienia wątroby. Informacje o pacjencie, w tym wyniki badania podmiotowego raz przedmiotowego przedstawiono odpowiednio w tabeli nr 1 i 2.

Tabela 1. Informacje o pacjencie

\begin{tabular}{|l|l|}
\hline \multicolumn{2}{|c|}{ DANE OSOBOWE } \\
\hline Wiek: 45 & Stan cywilny: rozwodnik \\
\hline Aktywność zawodowa: nie pracuje & Wykonywany zawód: kucharz \\
\hline \multicolumn{1}{|c|}{ HISTORIA CHOROBY } \\
\hline $\begin{array}{l}\text { Rozpoznanie lekarskie: Niewydolność wątroby przeszczepionej. Przewlekła } \\
\text { choroba nerek. }\end{array}$ \\
\hline Data przyjęcia do szpitala: 09.11.2018r. \\
\hline Oddział: Klinika Immunologii i Transplantologii i Chorób Zewnętrznych \\
\hline $\begin{array}{l}\text { Poprzednie hospitalizacje: } \\
\text { 05.06.2005r - przeszczepienie wątroby od dawcy zmarłego z powodu } \\
\text { niewydolności wątroby własnej w przebiegu autoimmunologicznego jej } \\
\text { zapalenia } \\
\text { 06.11.2018r. - Klinika Urologii, resekcja nerki prawej }\end{array}$ \\
\hline $\begin{array}{l}\text { Przebyte choroby: } \\
\text { - autoimmunologicznego zapalenia wątroby; } \\
\text { - przewlekła choroba nerek o niejasnej etiologii }\end{array}$ \\
\hline
\end{tabular}


Przebyte zabiegi operacyjne: przeszczepienie wątroby; resekcja guza nerki prawej

\begin{tabular}{|c|c|}
\hline Przyjmowane leki & Dawka \\
\hline Kalipoz & 1 t. x3 dziennie \\
\hline Magnez & x2 t. x3 dziennie \\
\hline Controloc & $40 \mathrm{mg} \times 1$ dziennie \\
\hline Encorton & $7,5 \mathrm{mg} \times 1$ dziennie \\
\hline Alfadiol & $0,25 \mathrm{ug} \times 1$ dziennie \\
\hline Advagraf & $2 \mathrm{mg} \times 1$ dziennie \\
\hline
\end{tabular}

\section{WYWIAD ŚRODOWISKOWY}

Członkowie najbliższej rodziny: rodzice i była żona

Ważne wydarzenia w rodzinie - ostatnie lata: rozwód w $2016 \mathrm{r}$.

Choroby występujące w rodzinie: brak

Hobby/zainteresowania: oglądanie filmów

Formy spędzania czasu wolnego: oglądanie telewizji, spacery z psem

Nałogi w rodzinie: brak

Błędy żywieniowe: nieregularnie przyjmowane posiłki, mało zbilansowana dieta

Ograniczenia/przeciążenia psychiczne/fizyczne: poruszanie się za pomocą balkonika, zaburzenia świadomości spowodowane encefalopatią wątrobową, stres spowodowany złym samopoczuciem i niewydolnością przeszczepionej wątroby, częsta agresja, brak stosowania się do zaleceń lekarskich i przyjmowania leków.

Ograniczone kontakty/brak wsparcia społecznego: rodzina nie odwiedza chorego w szpitalu, nie interesuje się jego stanem zdrowia.

Tabela 2. Badanie przedmiotowe 


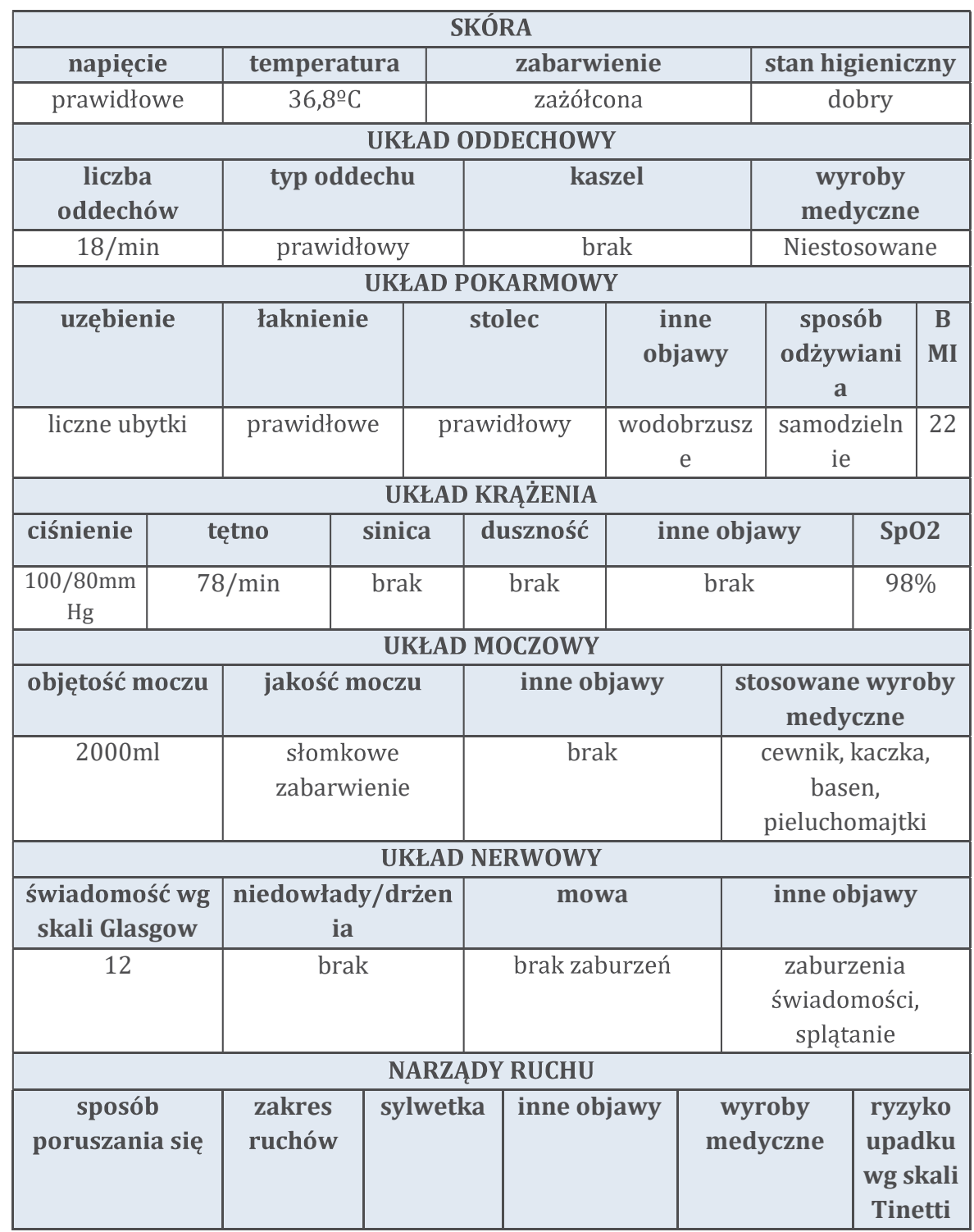




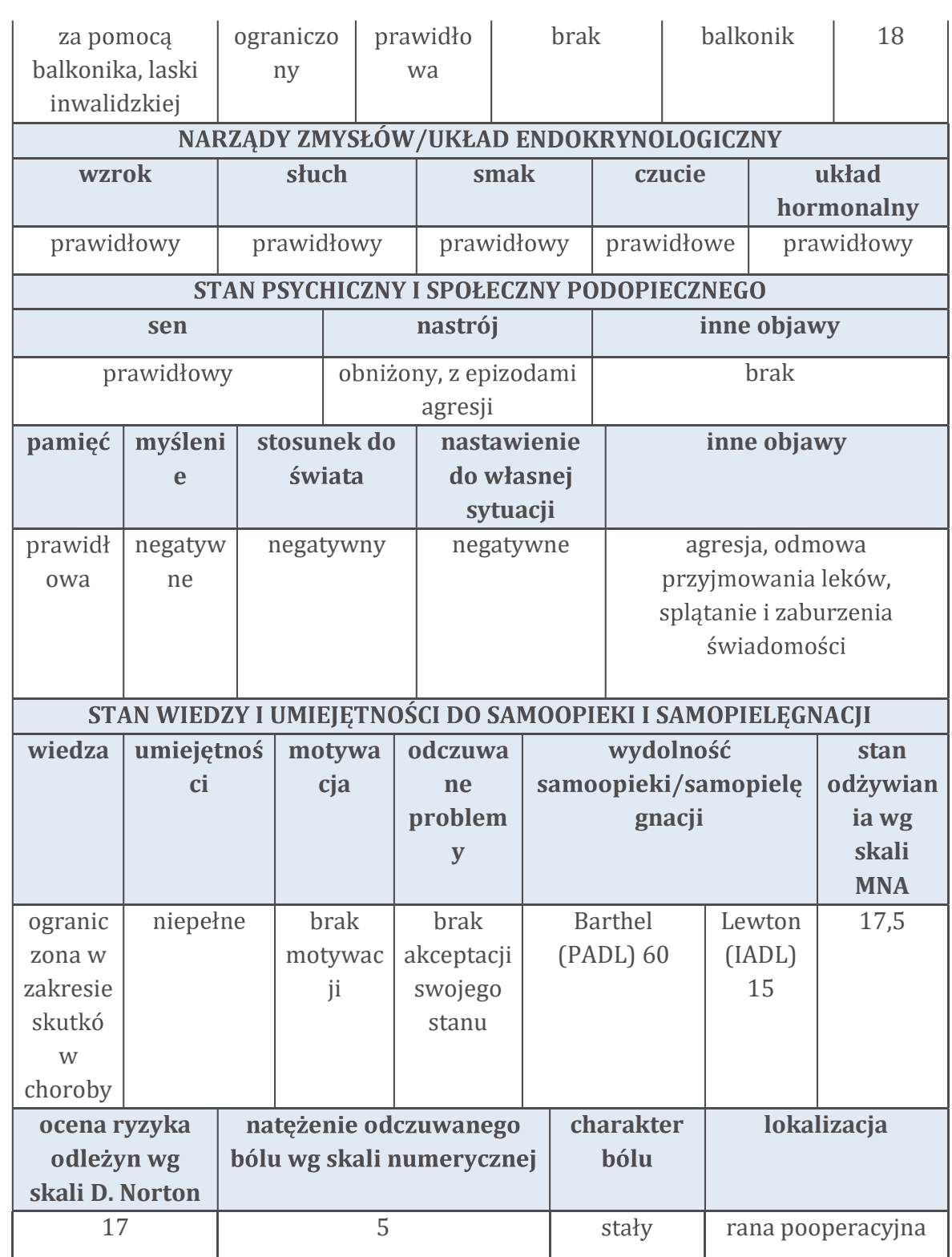




\begin{tabular}{|c|c|}
\hline \multicolumn{2}{|c|}{ KANIULE } \\
\hline typ wkłucia & miejsce \\
\hline obwodowe & lewe zgięcie dołu łokciowego \\
\hline obwodowe & prawy grzbiet dłoni \\
\hline
\end{tabular}

Tabela 3. Kategoria pacjenta

\begin{tabular}{|l|l|}
\hline $\begin{array}{c}\text { Oszacowana kategoria pacjenta wg } \\
\text { Lenartowicz }\end{array}$ & \multicolumn{1}{|c|}{ Stan pacjenta } \\
\hline II kategoria - pacjent wymagający \\
umiarkowanej opieki pielęgniarskiej & $\begin{array}{l}\text { Pacjent głównie leżący, częściowo } \\
\text { samodzielny, jednak potrzebujący } \\
\text { pomocy przy codziennych } \\
\text { czynnościach i wsparcia } \\
\text { psychicznego. }\end{array}$ \\
\hline
\end{tabular}

\section{Zaproponowany model opieki pielęgniarskiej}

Model opieki został opracowany według Virginii Henderson, która podkreśla znaczenie piramidy potrzeb według Masłowa [9]. Model ten polega na całościowym traktowaniu człowieka, zarówno zdrowego jak i chorego, który może funkcjonować dzięki hierarchicznemu zaspokajaniu czternastu uniwersalnych potrzeb. Odnoszą się do sfer fizjologicznych, psychologicznych i duchowych. Określenie deficytów w ich zakresie pozwala na realne wskazanie zapotrzebowania pacjenta na opiekę pielęgniarską. Funkcja pielęgniarki w tym modelu opieki polega na asystowaniu pacjentowi w zaspokajaniu tych potrzeb. Ma ona na celu pomóc pacjentowi w szybszym powrocie do zdrowia lub towarzyszenie mu i zapewnienie warunków godnej, spokojnej śmierci. Pielęgniarka sprawując opiekę nad pacjentem dąży do jak najszybszego uzyskania niezależności chorego poprzez opiekę pielęgniarską. Ponadto jej rolą jest także edukowanie pacjenta oraz promowanie zdrowia i zapobieganie powikłaniom choroby. Personel pielęgniarski pełni rolę uzupełniającą deficyt samoopieki u chorego, pomocnika oraz partnera [10]. 
Opisywany pacjent potrzebuje pomocy w zrozumieniu własnego stanu zdrowia, oraz $\mathrm{w}$ poprawie jakości życia w terminalnym stanie jego choroby. Potrzebuje również asystowania w czynnościach życia codziennego, zwłaszcza w chodzeniu, toalecie i czynnościach higienicznych, a także $\mathrm{w}$ sferze psychicznej. W tym aspekcie szczególnie potrzebuje pomocy i wsparcia w pogodzeniu się z chorobą oraz zwalczeniu uczucia samotności, ponieważ nie otrzymuje on wsparcia od swojej rodziny. Zdiagnozowane problemy pielęgnacyjne pacjenta i zaplanowane działanie zostało przedstawione w tabelach 4-20.

Tabela 4.

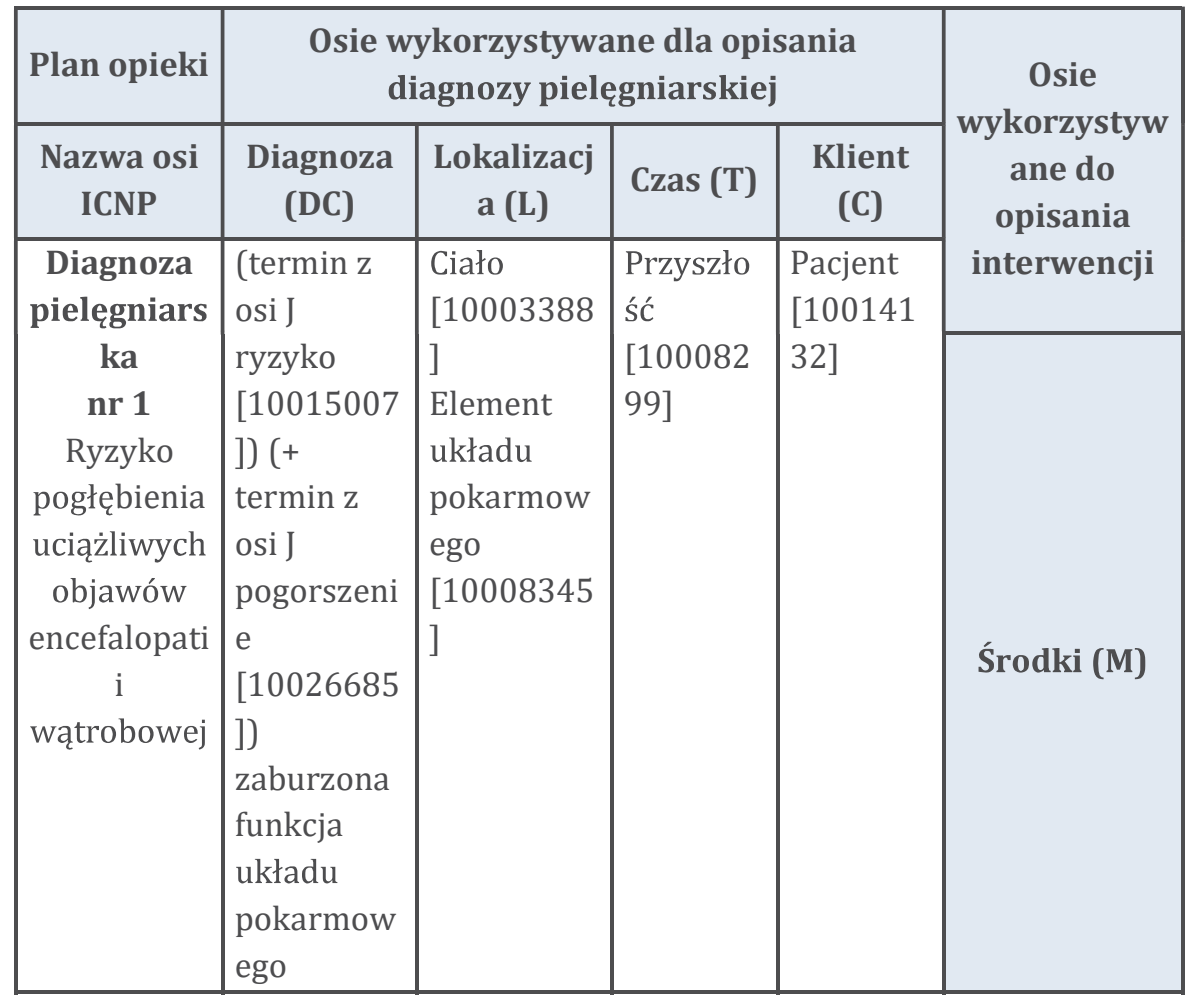


Innowacje w Pielęgniarstwie i Naukach o Zdrowiu $\quad 4$ (4)/2019

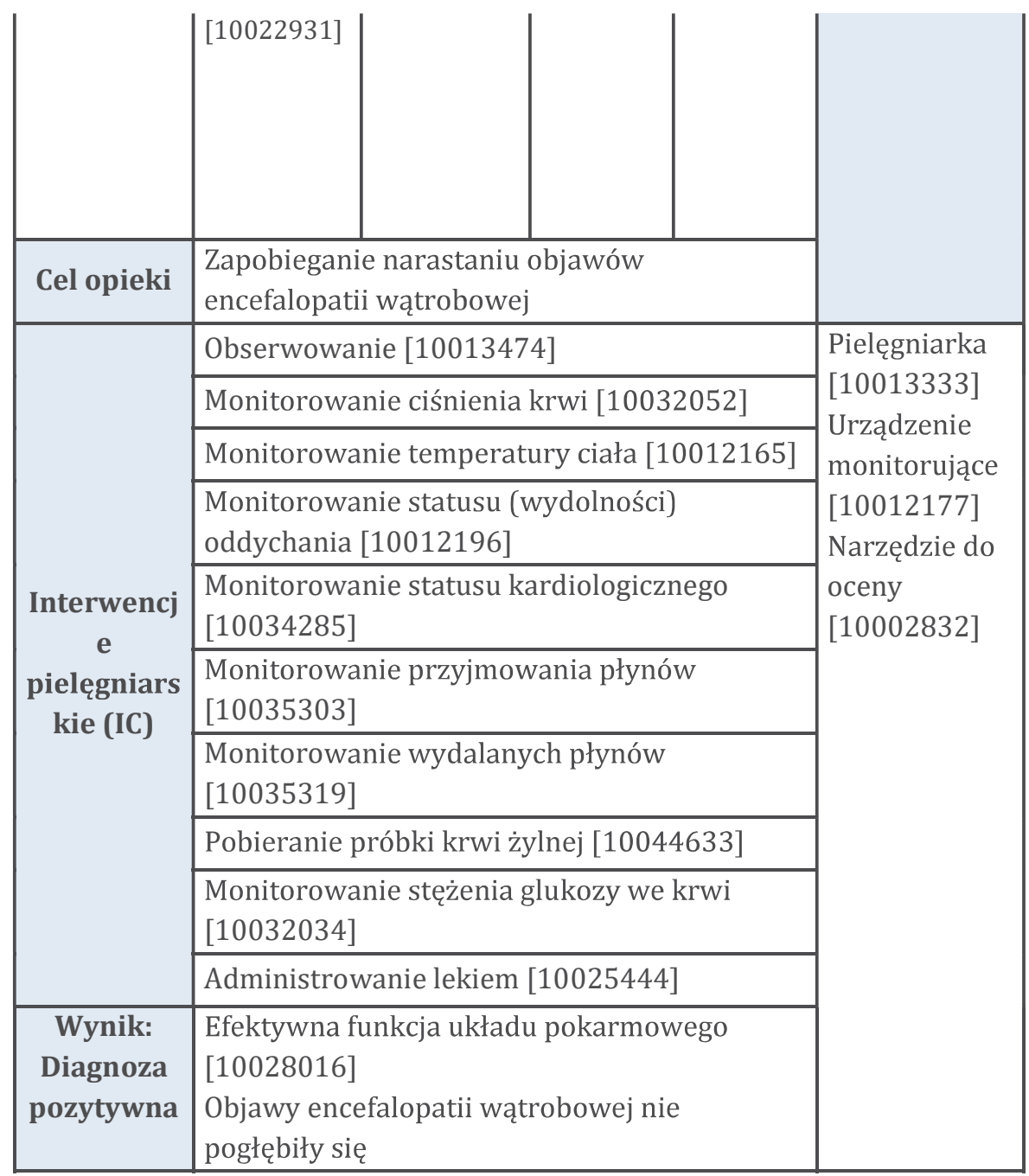


Tabela 5.

\begin{tabular}{|c|c|c|c|c|c|}
\hline \begin{tabular}{|l|} 
Plan \\
opieki
\end{tabular} & Osie v & $\begin{array}{l}\text { ykorzysty } \\
\text { iagnozy p }\end{array}$ & $\begin{array}{l}\text { wane dla op } \\
\text { elęgniarskie }\end{array}$ & sania & \\
\hline $\begin{array}{l}\text { Nazwa osi } \\
\text { ICNP }\end{array}$ & $\begin{array}{l}\text { Diagnoza } \\
\text { (DC) }\end{array}$ & $\begin{array}{c}\text { Lokaliza } \\
\text { cja (L) }\end{array}$ & Czas (T) & $\begin{array}{l}\text { Klient } \\
\text { (C) }\end{array}$ & $\begin{array}{c}\text { Osie } \\
\text { wykorzystyw }\end{array}$ \\
\hline $\begin{array}{c}\text { Diagnoza } \\
\text { pielęgniars } \\
\text { ka } \\
\text { nr } 2 \\
\text { Dyskomfort }\end{array}$ & $\begin{array}{l}\text { Obrzęk } \\
\text { limfatyczn } \\
\text { y } \\
{[1003000} \\
3] \text { C+ }^{+}\end{array}$ & $\begin{array}{l}\text { Ciało } \\
{[100033} \\
88] \\
\text { Noga } \\
{[100112}\end{array}$ & $\begin{array}{l}\text { Teraźniejsz } \\
\text { ość } \\
{[10015581} \\
]\end{array}$ & $\begin{array}{l}\text { Pacjent } \\
{[100141} \\
32]\end{array}$ & $\begin{array}{c}\text { ane do } \\
\text { opisania } \\
\text { interwencji }\end{array}$ \\
\hline $\begin{array}{c}\text { wodobrzusz } \\
\text { em i } \\
\text { obrzękami } \\
\text { kończyn } \\
\text { dolnych }\end{array}$ & $\begin{array}{l}\text { osi F } \\
\text { wodobrzu } \\
\text { sze } \\
\text { [1004194 } \\
6] \text { ) }\end{array}$ & & & & Środki (M) \\
\hline Cel opieki & \multicolumn{4}{|c|}{$\begin{array}{l}\text { Poprawa samopoczucia pacjenta i } \\
\text { zmniejszenie obrzęków }\end{array}$} & \\
\hline \multirow{9}{*}{$\begin{array}{c}\text { Interwencj } \\
\text { e } \\
\text { pielęgniars } \\
\text { kie (IC) }\end{array}$} & \multicolumn{4}{|c|}{ Edukowanie [10006564] } & \multirow{9}{*}{$\begin{array}{l}\text { Pielęgniarka } \\
\text { [10013333] } \\
\text { Materiał } \\
\text { dydaktyczny } \\
\text { [10011251] } \\
\text { Narzędzie do } \\
\text { oceny } \\
\text { [10002832] } \\
\text { Usługa } \\
\text { edukacji } \\
\text { zdrowotnej } \\
\text { [10039459] }\end{array}$} \\
\hline & \multicolumn{4}{|c|}{ Ocenianie obrzęku [10045177] } & \\
\hline & \multicolumn{4}{|c|}{ Zarządzanie obrzękiem [10036793] } & \\
\hline & \multicolumn{4}{|c|}{ Obserwowanie [10013474] } & \\
\hline & \multicolumn{4}{|c|}{ Ważenie pacjenta [10033323] } & \\
\hline & \multicolumn{4}{|c|}{ Masowanie [10011768] } & \\
\hline & \multicolumn{4}{|c|}{$\begin{array}{l}\text { Monitorowanie przyjmowania płynów } \\
\text { [10035303] }\end{array}$} & \\
\hline & \multicolumn{4}{|c|}{$\begin{array}{l}\text { Monitorowanie wydalanych płynów } \\
\text { [10035319] }\end{array}$} & \\
\hline & \multicolumn{4}{|c|}{ Administrowanie lekiem [10025444] } & \\
\hline
\end{tabular}




\begin{tabular}{|c|l|}
\cline { 2 - 3 } Wynik: & Bez obrzęków obwodowych [10029020] \\
Diagnoza & Samopoczucie pacjenta poprawiło się, chory \\
pozytywna & odczuwa mniejszy dyskomfort wywołany \\
& wodobrzuszem, obrzęki kończyn dolnych \\
& zaczęły się stopniowo zmniejszać
\end{tabular}

\section{Tabela 6.}

\begin{tabular}{|c|c|c|c|c|c|}
\hline Plan opieki & \multicolumn{4}{|c|}{$\begin{array}{l}\text { Osie wykorzystywane dla opisania } \\
\text { diagnozy pielęgniarskiej }\end{array}$} & \multirow{3}{*}{$\begin{array}{c}\text { Osie } \\
\text { wykorzysty } \\
\text { wane do } \\
\text { opisania } \\
\text { interwencji }\end{array}$} \\
\hline $\begin{array}{l}\text { Nazwa osi } \\
\text { ICNP }\end{array}$ & $\begin{array}{l}\text { Diagnoza } \\
\text { (DC) }\end{array}$ & $\begin{array}{l}\text { Lokaliza } \\
\text { cja (L) }\end{array}$ & Czas (T) & $\begin{array}{l}\text { Klient } \\
\text { (C) }\end{array}$ & \\
\hline \multirow{2}{*}{$\begin{array}{c}\text { Diagnoza } \\
\text { pielęgniarsk } \\
\text { a } \\
\text { nr } \mathbf{3} \\
\text { Niestosowani } \\
\text { e się do } \\
\text { zaleceń } \\
\text { farmakologicz } \\
\text { nych }\end{array}$} & \multirow{2}{*}{$\begin{array}{l}\text { Nieprzestrze } \\
\text { ganie reżimu } \\
\text { leku } \\
{[10021682]}\end{array}$} & \multirow[t]{2}{*}{$\begin{array}{l}\text { Ciało } \\
{[100033} \\
88]\end{array}$} & \multirow{2}{*}{$\begin{array}{l}\text { Przyszło } \\
\text { ść } \\
{[100082} \\
99]\end{array}$} & \multirow[t]{2}{*}{$\begin{array}{l}\text { Pacjent } \\
{[100141} \\
32]\end{array}$} & \\
\hline & & & & & Środki (M) \\
\hline Cel opieki & $\begin{array}{l}\text { Współpraca p } \\
\text { terapeutyczny }\end{array}$ & m & społem & & \\
\hline \multirow{6}{*}{$\begin{array}{l}\text { Interwencje } \\
\text { pielęgniarski } \\
\text { e (IC) }\end{array}$} & \multicolumn{4}{|c|}{$\begin{array}{l}\text { Motywowanie [10012242] (+ termin z osi F } \\
\text { przestrzeganie reżimu leku [10030354] }\end{array}$} & $\begin{array}{l}\text { Pielęgniarka } \\
\text { [10013333] }\end{array}$ \\
\hline & \multicolumn{4}{|c|}{$\begin{array}{l}\text { Monitorowanie przestrzegania leczenia } \\
\text { [10043878] }\end{array}$} & $\begin{array}{l}\text { Lekarz } \\
{[10014522]}\end{array}$ \\
\hline & \multicolumn{4}{|c|}{ Edukowanie [10006564] } & Materiał \\
\hline & \multicolumn{4}{|c|}{ Nauczanie o leku [10019470] } & dydaktyczny \\
\hline & \multicolumn{4}{|c|}{ Nauczanie o podawaniu leku [10040712] } & [10011251] \\
\hline & \multicolumn{4}{|c|}{$\begin{array}{l}\text { Promowanie przestrzegania zaleceń } \\
\text { przyjmowania leków [10038051] }\end{array}$} & edukacji \\
\hline
\end{tabular}




\begin{tabular}{c|l|l|}
\cline { 2 - 3 } Wynik: & Przestrzeganie reżimu leku [10030192] & zdrowotnej \\
Diagnoza & Pacjent zaczął częściowo współpracować. & Przyjmuje leki jedynie po każdorazowej \\
pozytywna & namowie personelu pielęgniarskiego & \\
\hline
\end{tabular}

Tabela 7.

\begin{tabular}{|c|c|c|c|c|c|}
\hline Plan opieki & \multicolumn{4}{|c|}{$\begin{array}{c}\text { Osie wykorzystywane dla opisania } \\
\text { diagnozy pielęgniarskiej }\end{array}$} & \multirow{3}{*}{$\begin{array}{c}\text { Osie } \\
\text { wykorzystyw } \\
\text { ane do } \\
\text { opisania } \\
\text { interwencji }\end{array}$} \\
\hline $\begin{array}{l}\text { Nazwa osi } \\
\text { ICNP }\end{array}$ & $\begin{array}{l}\text { Diagnoza } \\
\text { (DC) }\end{array}$ & $\begin{array}{l}\text { Lokalizac } \\
\text { ja (L) }\end{array}$ & Czas (T) & $\begin{array}{l}\text { Klient } \\
\text { (C) }\end{array}$ & \\
\hline \multirow{2}{*}{$\begin{array}{c}\text { Diagnoza } \\
\text { pielęgniars } \\
\text { ka } \\
\text { nr 5 } \\
\text { Ryzyko } \\
\text { zakażenia } \\
\text { kaniuli } \\
\text { obwodowyc } \\
\text { h }\end{array}$} & \multirow{2}{*}{$\begin{array}{l}\text { Ryzyko } \\
\text { infekcji } \\
{[1001513} \\
3]\end{array}$} & \multirow{2}{*}{$\begin{array}{c}\text { Ciało } \\
{[1000338} \\
8] \\
\text { Żyła } \\
{[1002066} \\
5]\end{array}$} & \multirow{2}{*}{$\begin{array}{l}\text { Przyszłoś } \\
\text { ć } \\
{[1000829} \\
9]\end{array}$} & \multirow{2}{*}{\begin{tabular}{|l} 
Pacjent \\
{$[1001413$} \\
$2]$
\end{tabular}} & \\
\hline & & & & & Środki (M) \\
\hline Cel opieki & $\begin{array}{l}\text { Zminimaliz } \\
\text { obwodowy }\end{array}$ & $\begin{array}{l}\text { towanie ryz } \\
\text { ch }\end{array}$ & zakażer & a kaniuli & \\
\hline \multirow{4}{*}{$\begin{array}{l}\text { Interwencje } \\
\text { pielęgniars } \\
\text { kie (IC) }\end{array}$} & \multicolumn{4}{|c|}{ Prewencja infekcji [10036916] } & \multirow{5}{*}{$\begin{array}{l}\text { Pielęgniarka } \\
\text { [10013333] } \\
\text { Urządzenie } \\
\text { monitorujące } \\
\text { [10012177] } \\
\text { Technika } \\
\text { aseptyczna } \\
\text { [10002639] }\end{array}$} \\
\hline & \multicolumn{4}{|c|}{ Ocenianie podatności na infekcję [10002821] } & \\
\hline & \multicolumn{4}{|c|}{$\begin{array}{l}\text { Zastosowanie technik aseptycznych } \\
\text { [10041784] }\end{array}$} & \\
\hline & \multicolumn{4}{|c|}{$\begin{array}{l}\text { Monitorowanie objawów przedmiotowych i } \\
\text { objawów podmiotowych infekcji [10012203] }\end{array}$} & \\
\hline $\begin{array}{c}\text { Wynik: } \\
\text { Diagnoza } \\
\text { pozytywna }\end{array}$ & \multicolumn{4}{|c|}{$\begin{array}{l}\text { Bez infekcji [10028945] } \\
\text { Nie wystąpiło zakażenie kaniuli } \\
\text { obwodowych }\end{array}$} & \\
\hline
\end{tabular}

Tabela 8. 


\begin{tabular}{|c|c|c|c|c|c|}
\hline Plan opieki & \multicolumn{4}{|c|}{$\begin{array}{c}\text { Osie wykorzystywane dla opisania } \\
\text { diagnozy pielęgniarskiej }\end{array}$} & \multirow{3}{*}{$\begin{array}{c}\text { Osie } \\
\text { wykorzystyw } \\
\text { ane do } \\
\text { opisania } \\
\text { interwencji }\end{array}$} \\
\hline $\begin{array}{l}\text { Nazwa osi } \\
\text { ICNP }\end{array}$ & $\begin{array}{l}\text { Diagnoza } \\
\text { (DC) }\end{array}$ & $\begin{array}{l}\text { Lokalizac } \\
\text { ja (L) }\end{array}$ & Czas (T) & $\begin{array}{l}\text { Klient } \\
\text { (C) }\end{array}$ & \\
\hline \multirow[b]{2}{*}{$\begin{array}{c}\text { Diagnoza } \\
\text { pielęgniars } \\
\text { ka } \\
\text { nr } 6 \\
\text { Ryzyko } \\
\text { zakażenia } \\
\text { układu } \\
\text { moczowego } \\
\text { spowodowa } \\
\text { ne } \\
\text { obecnością } \\
\text { cewnika } \\
\text { urologiczneg } \\
\text { o }\end{array}$} & \multirow{2}{*}{$\begin{array}{l}\text { Ryzyko } \\
\text { infekcji } \\
{[1001513} \\
3]\end{array}$} & \multirow{2}{*}{$\begin{array}{l}\text { Ciało } \\
{[1000338} \\
8] \\
\text { Pęcherz } \\
\text { moczowy } \\
{[1002036} \\
0]\end{array}$} & \multirow{2}{*}{$\begin{array}{l}\text { Przyszłoś } \\
\text { ć } \\
{[1000829} \\
9]\end{array}$} & \multirow{2}{*}{$\begin{array}{l}\text { Pacjent } \\
{[1001413} \\
2]\end{array}$} & \\
\hline & & & & & \multirow[t]{2}{*}{ Środki (M) } \\
\hline Cel opieki & \multicolumn{4}{|c|}{$\begin{array}{l}\text { Zminimalizowanie ryzyka zakażenia układu } \\
\text { moczowego }\end{array}$} & \\
\hline \multirow{7}{*}{$\begin{array}{c}\text { Interwencje } \\
\text { pielęgniars } \\
\text { kie (IC) }\end{array}$} & \multicolumn{4}{|c|}{ Prewencja infekcji [10036916] } & \multirow{7}{*}{$\begin{array}{l}\text { Pielęgniarka } \\
\text { [10013333] } \\
\text { Urządzenie } \\
\text { monitorujące } \\
\text { [10012177] } \\
\text { Cewnik } \\
\text { urologiczny } \\
\text { [10020373] } \\
\text { Urządzenie } \\
\text { do kąpieli } \\
\text { [10003147] } \\
\text { Mydło }\end{array}$} \\
\hline & \multicolumn{4}{|c|}{$\begin{array}{l}\text { Zastosowanie technik aseptycznych } \\
\text { [10041784] }\end{array}$} & \\
\hline & \multicolumn{4}{|c|}{ Ocenianie podatności na infekcję [10002821] } & \\
\hline & \multicolumn{4}{|c|}{$\begin{array}{l}\text { Monitorowanie objawów przedmiotowych i } \\
\text { objawów podmiotowych infekcji [10012203] }\end{array}$} & \\
\hline & \multicolumn{4}{|c|}{$\begin{array}{l}\text { Zarządzanie cewnikiem urologicznym } \\
\text { [10031977] }\end{array}$} & \\
\hline & \multicolumn{4}{|c|}{$\begin{array}{l}\text { Pielęgnacja cewnika urologicznego } \\
\text { [10033277] }\end{array}$} & \\
\hline & \multicolumn{4}{|c|}{ Pielęgnacja krocza [10045154] } & \\
\hline
\end{tabular}




\begin{tabular}{|c|l|l|}
\cline { 2 - 3 } & Asystowanie w higienie [10030821] & {$[10018358]$} \\
\hline Wynik: & Bez infekcji [10028945] & toaletowy \\
Diagnoza & Nie wystąpiło zakażenie układu moczowego, & toán \\
pozytywna & utrzymano właściwą higienę okolic krocza i & {$[10017487]$} \\
& cewki moczowej & Technika \\
& & aseptyczna \\
& & {$[10002639]$} \\
\hline
\end{tabular}

Tabela 9.

\begin{tabular}{|c|c|c|c|c|c|}
\hline Plan opieki & \multicolumn{4}{|c|}{$\begin{array}{l}\text { Osie wykorzystywane dla opisania } \\
\text { diagnozy pielęgniarskiej }\end{array}$} & \multirow{3}{*}{$\begin{array}{c}\text { Osie } \\
\text { wykorzystyw } \\
\text { ane do } \\
\text { opisania } \\
\text { interwencji }\end{array}$} \\
\hline $\begin{array}{l}\text { Nazwa osi } \\
\text { ICNP }\end{array}$ & $\begin{array}{l}\text { Diagnoza } \\
\text { (DC) }\end{array}$ & $\begin{array}{l}\text { Lokalizac } \\
\text { ja (L) }\end{array}$ & Czas (T) & $\begin{array}{l}\text { Klient } \\
\text { (C) }\end{array}$ & \\
\hline \multirow{2}{*}{$\begin{array}{c}\text { Diagnoza } \\
\text { pielęgniars } \\
\text { ka } \\
\text { nr } 7 \\
\text { Ryzyko } \\
\text { upadku }\end{array}$} & \multirow{2}{*}{$\begin{array}{l}\text { Ryzyko } \\
\text { upadku } \\
{[1001512} \\
2]\end{array}$} & \multirow{2}{*}{$\begin{array}{l}\text { Ciało } \\
{[1000338} \\
8]\end{array}$} & \multirow{2}{*}{\begin{tabular}{|l} 
Przyszłoś \\
ć \\
{$[1000829$} \\
$9]$
\end{tabular}} & \multirow{2}{*}{$\begin{array}{l}\text { Pacjent } \\
{[1001413} \\
2]\end{array}$} & \\
\hline & & & & & \multirow[t]{2}{*}{ Środki (M) } \\
\hline Cel opieki & \multicolumn{4}{|c|}{$\begin{array}{l}\text { Zminimalizowanie ryzyka upadku, } \\
\text { zapewnienie bezpieczeństwa pacjentowi }\end{array}$} & \\
\hline \multirow{6}{*}{$\begin{array}{c}\text { Interwencje } \\
\text { pielęgniars } \\
\text { kie (IC) }\end{array}$} & \multicolumn{4}{|c|}{$\begin{array}{l}\text { Monitorowanie oznak życiowych } \\
\text { [10032113] }\end{array}$} & \multirow{6}{*}{$\begin{array}{l}\text { Pielęgniarka } \\
\text { [10013333] } \\
\text { Technika } \\
\text { chodzenia } \\
\text { [10002222] } \\
\text { Laska } \\
\text { inwalidzka } \\
\text { [10020893] }\end{array}$} \\
\hline & \multicolumn{4}{|c|}{ Monitorowanie ryzyka upadku [10037442] } & \\
\hline & \multicolumn{4}{|c|}{$\begin{array}{l}\text { Demonstrowanie prewencji upadków } \\
{[10040248]}\end{array}$} & \\
\hline & \multicolumn{4}{|c|}{$\begin{array}{l}\text { Dostarczanie urządzeń zabezpieczających } \\
\text { [10024527] }\end{array}$} & \\
\hline & \multicolumn{4}{|c|}{$\begin{array}{l}\text { Nauczanie o technikach przemieszczania się } \\
\text { [10041489] }\end{array}$} & \\
\hline & \multicolumn{4}{|c|}{ Ocenianie ryzyka upadków [10023520] } & \\
\hline
\end{tabular}




\begin{tabular}{|c|l|}
\hline \multirow{2}{*}{} & Nauczanie profilaktyki upadków [10040253] \\
\cline { 2 - 3 } & Zapobieganie upadkowi [10040211] \\
\cline { 2 - 3 } & $\begin{array}{l}\text { Ocenianie przestrzegania zaleceń } \\
{[10024185]}\end{array}$ \\
\hline \multirow{2}{*}{$\begin{array}{c}\text { Dynik: } \\
\text { pozytywna }\end{array}$} & $\begin{array}{l}\text { Brak upadku [10034704] } \\
\text { Pacjent swobodnie porusza się w obrębie sali } \\
\text { przy pomocy balkonika lub laski } \\
\text { inwalidzkiej. Ryzyko upadku nie zostało } \\
\text { zminimalizowane, jednak zapewniono } \\
\text { bezpieczeństwo choremu podczas } \\
\text { poruszania się. }\end{array}$ \\
\hline
\end{tabular}

Tabela 10.

\begin{tabular}{|c|c|c|c|c|c|}
\hline Plan opieki & \multicolumn{4}{|c|}{$\begin{array}{c}\text { Osie wykorzystywane dla opisania } \\
\text { diagnozy pielęgniarskiej }\end{array}$} & \multirow{3}{*}{$\begin{array}{c}\text { Osie } \\
\text { wykorzystyw } \\
\text { ane do } \\
\text { opisania } \\
\text { interwencji }\end{array}$} \\
\hline $\begin{array}{l}\text { Nazwa osi } \\
\text { ICNP }\end{array}$ & $\begin{array}{l}\text { Diagnoza } \\
\text { (DC) }\end{array}$ & $\begin{array}{l}\text { Lokaliza } \\
\text { cja (L) }\end{array}$ & Czas (T) & $\begin{array}{l}\text { Klient } \\
\text { (C) }\end{array}$ & \\
\hline $\begin{array}{c}\text { Diagnoza } \\
\text { pielęgniarsk } \\
\text { a } \\
\text { nr } 8 \\
\text { Ryzyko }\end{array}$ & $\begin{array}{l}\text { (termin z } \\
\text { osi J } \\
\text { ryzyko } \\
\text { [1001500 } \\
7] \text { ) }\end{array}$ & $\begin{array}{l}\text { Ciało } \\
{[100033} \\
88] \\
\text { Żyła } \\
{[100206}\end{array}$ & $\begin{array}{l}\text { Przyszłoś } \\
\text { ć } \\
{[100082} \\
99]\end{array}$ & $\begin{array}{l}\text { Pacjent } \\
{[100141} \\
32]\end{array}$ & \\
\hline
\end{tabular}




\begin{tabular}{|c|c|c|c|}
\hline Innowacje w & gniars & Nauka & $4(4) / 2($ \\
\hline $\begin{array}{c}\text { niedrożności } \\
\text { kaniuli } \\
\text { obwodowych } \\
\text { spowodowane } \\
\text { brakiem } \\
\text { przyjmowania } \\
\text { stałych leków } \\
\text { dożylnych i } \\
\text { wynikające z } \\
\text { tego ryzyko } \\
\text { zakrzepowego } \\
\text { zapalenia żył } \\
\text { powierzchnio } \\
\text { wych }\end{array}$ & $\begin{array}{l}\text { zapalenie } \\
{[1002992} \\
7]+ \\
\text { termin z } \\
\text { osi F } \\
\text { dostęp } \\
\text { dożylny } \\
{[1001078} \\
0])\end{array}$ & 65] & Środki (M) \\
\hline Cel opieki & \multicolumn{2}{|c|}{$\begin{array}{l}\text { Zminimalizowanie ryzyka niedrożności } \\
\text { kaniuli obwodowych }\end{array}$} & \\
\hline \multirow{9}{*}{$\begin{array}{c}\text { Interwencje } \\
\text { pielęgniarski } \\
\text { e (IC) }\end{array}$} & \multicolumn{2}{|c|}{$\begin{array}{l}\text { Utrzymywanie drożności dostępu dożylnego } \\
\text { [10036577] }\end{array}$} & \multirow{9}{*}{\begin{tabular}{|l} 
Pielęgniarka \\
{$[10013333]$} \\
Terapia \\
dożylna \\
{$[10010808]$} \\
Kaniula \\
dożylna \\
{$[10020677]$} \\
Urządzenie \\
monitorujące \\
{$[10012177]$}
\end{tabular}} \\
\hline & \multicolumn{2}{|c|}{ Monitorowanie oznak życiowych } & \\
\hline & \multicolumn{2}{|c|}{$\begin{array}{l}\text { Monitorowanie odpowiedzi na leczenie } \\
\text { [10032109] }\end{array}$} & \\
\hline & \multicolumn{2}{|c|}{$\begin{array}{l}\text { Monitorowanie efektów ubocznych } \\
\text { działania leku [10043884] }\end{array}$} & \\
\hline & \multicolumn{2}{|c|}{ Terapia przeciwzakrzepowa [10039284] } & \\
\hline & \multicolumn{2}{|c|}{$\begin{array}{l}\text { Administrowanie lekiem dożylnym } \\
\text { [10045836] }\end{array}$} & \\
\hline & \multicolumn{2}{|c|}{$\begin{array}{l}\text { Pielęgnacja miejsca wprowadzenia } \\
\text { urządzeń inwazyjnych [10031592] }\end{array}$} & \\
\hline & \multicolumn{2}{|c|}{ Używanie techniki aseptycznej [10041784] } & \\
\hline & \multicolumn{2}{|c|}{$\begin{array}{l}\text { Nauczanie o terapii przeciwzakrzepowej } \\
\text { [10036531] }\end{array}$} & \\
\hline
\end{tabular}




\begin{tabular}{|c|l|}
\cline { 2 - 2 } Wynik: & Efektywny status sercowo-naczyniowy \\
Diagnoza & Kaniule dożylne są drożne, a ryzyko \\
pozytywna & $\begin{array}{l}\text { niedrożności zostało zmniejszone, } \\
\text { nie wystąpiły powikłania zakrzepowo- } \\
\end{array}$ \\
& zatorowe
\end{tabular}

\section{Tabela 11.}

\begin{tabular}{|c|c|c|c|c|c|}
\hline Plan opieki & Osie v & $\begin{array}{l}\text { ykorzysty } \\
\text { iagnozy p }\end{array}$ & $\begin{array}{l}\text { wane dla opi } \\
\text { elęgniarskie }\end{array}$ & sania & \multirow{3}{*}{$\begin{array}{c}\text { Osie } \\
\text { wykorzystyw } \\
\text { ane do } \\
\text { opisania } \\
\text { interwencji }\end{array}$} \\
\hline $\begin{array}{l}\text { Nazwa osi } \\
\text { ICNP }\end{array}$ & $\begin{array}{l}\text { Diagnoza } \\
\text { (DC) }\end{array}$ & $\begin{array}{c}\text { Lokaliza } \\
\text { cja (L) }\end{array}$ & Czas (T) & $\begin{array}{l}\text { Klient } \\
\text { (C) }\end{array}$ & \\
\hline \multirow{2}{*}{$\begin{array}{c}\text { Diagnoza } \\
\text { pielęgniars } \\
\text { ka } \\
\text { nr } 9 \\
\text { Dyskomfort } \\
\text { spowodowa } \\
\text { ny bólem } \\
\text { rany } \\
\text { pooperacyj } \\
\text { nej }\end{array}$} & \multirow{2}{*}{$\begin{array}{l}\text { Ból } \\
{[1002313} \\
0] \\
\text { (+termin } \\
\text { z osi F } \\
\text { rana } \\
\text { chirurgicz } \\
\text { na } \\
\text { [1001926 } \\
\text { 5]) }\end{array}$} & \multirow[t]{2}{*}{$\begin{array}{l}\text { Ciało } \\
{[100033} \\
88] \\
\text { Skóra } \\
{[100182} \\
39]\end{array}$} & \multirow[t]{2}{*}{$\begin{array}{l}\text { Teraźniejsz } \\
\text { ość } \\
{[10015581} \\
]\end{array}$} & \multirow[t]{2}{*}{$\begin{array}{l}\text { Pacjent } \\
{[100141} \\
32]\end{array}$} & \\
\hline & & & & & Środki (M) \\
\hline Cel opieki & \multicolumn{4}{|c|}{ e dolegliwości bólowych } & \\
\hline \multirow{6}{*}{$\begin{array}{c}\text { Interwencj } \\
\text { e } \\
\text { pielęgniars } \\
\text { kie (IC) }\end{array}$} & \multicolumn{4}{|c|}{ Ocenianie bólu [10026119] } & \multirow{6}{*}{$\begin{array}{l}\text { Pielęgniarka } \\
\text { [10013333] } \\
\text { Urządzenie } \\
\text { monitorujące } \\
\text { [10012177] } \\
\text { Narzędzie } \\
\text { do oceny } \\
\text { [10002832] }\end{array}$} \\
\hline & \multicolumn{4}{|c|}{ Monitorowanie bólu [10038929] } & \\
\hline & \multicolumn{4}{|c|}{ Monitorowanie ciśnienia krwi [10032052] } & \\
\hline & \multicolumn{4}{|c|}{ Monitorowanie temperatury ciała [10012165] } & \\
\hline & \multicolumn{4}{|c|}{$\begin{array}{l}\text { Monitorowanie statusu (wydolności) } \\
\text { oddychania [10012196] }\end{array}$} & \\
\hline & \multicolumn{4}{|c|}{ Monitorowanie statusu kardiologicznego } & \\
\hline
\end{tabular}




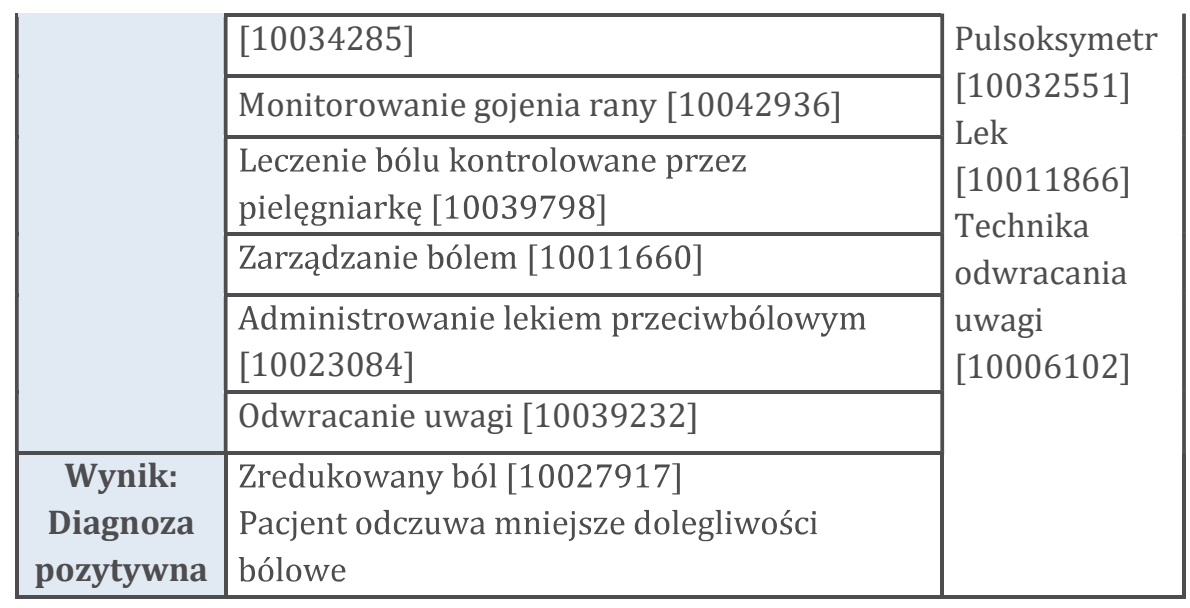


Tabela 12.

\begin{tabular}{|c|c|c|c|c|c|}
\hline Plan opieki & \multicolumn{4}{|c|}{$\begin{array}{l}\text { Osie wykorzystywane dla opisania } \\
\text { diagnozy pielęgniarskiej }\end{array}$} & \multirow{3}{*}{$\begin{array}{c}\text { Osie } \\
\text { wykorzystyw } \\
\text { ane do } \\
\text { opisania } \\
\text { interwencji }\end{array}$} \\
\hline $\begin{array}{l}\text { Nazwa osi } \\
\text { ICNP }\end{array}$ & $\begin{array}{l}\text { Diagnoz } \\
\text { a (DC) }\end{array}$ & $\begin{array}{c}\text { Lokaliza } \\
\text { cja (L) }\end{array}$ & Czas (T) & $\begin{array}{l}\text { Klient } \\
\text { (C) }\end{array}$ & \\
\hline \multirow{2}{*}{$\begin{array}{c}\text { Diagnoza } \\
\text { pielęgniars } \\
\text { ka } \\
\text { nr } 10 \\
\text { Niepokój } \\
\text { związany z } \\
\text { zaburzenia } \\
\text { mi } \\
\text { świadomośc } \\
\text { i }\end{array}$} & \multirow{2}{*}{$\begin{array}{l}\text { Zaburzon } \\
\text { a } \\
\text { zdolność } \\
\text { percepcji } \\
{[100226} \\
19]\end{array}$} & \multirow{2}{*}{$\begin{array}{l}\text { Ciało } \\
{[100033} \\
88]\end{array}$} & \multirow{2}{*}{$\begin{array}{l}\text { Teraźniejsz } \\
\text { ość } \\
\text { [10015581] }\end{array}$} & \multirow{2}{*}{$\begin{array}{l}\text { Pacjent } \\
{[100141} \\
32]\end{array}$} & \\
\hline & & & & & \multirow[t]{2}{*}{ Środki (M) } \\
\hline Cel opieki & \multicolumn{4}{|c|}{$\begin{array}{l}\text { Poprawa zdolności poczucia świadomości, } \\
\text { zmniejszenie poziomu nasilenia niepokoju }\end{array}$} & \\
\hline \multirow{8}{*}{$\begin{array}{c}\text { Interwencj } \\
\text { e } \\
\text { pielęgniars } \\
\text { kie (IC) }\end{array}$} & \multicolumn{4}{|c|}{$\begin{array}{l}\text { Identyfikowanie zmienionej percepcji } \\
\text { [10035697] }\end{array}$} & \multirow{8}{*}{$\begin{array}{l}\text { Pielęgniarka } \\
\text { [10013333] } \\
\text { Urządzenie } \\
\text { monitorujące } \\
\text { [10012177] } \\
\text { Narzędzie } \\
\text { do oceny } \\
\text { [10002832] } \\
\text { Terapia } \\
\text { reminiscencyj } \\
\text { na } \\
\text { [10016759] } \\
\text { Terapia }\end{array}$} \\
\hline & \multicolumn{4}{|c|}{ Obserwacja zmienionej percepcji [10013517] } & \\
\hline & \multicolumn{4}{|c|}{ Zarządzanie niepokojem [10031711] } & \\
\hline & \multicolumn{4}{|c|}{$\begin{array}{l}\text { Zarządzanie zaburzonym procesem radzenia } \\
\text { sobie }[10031846]\end{array}$} & \\
\hline & \multicolumn{4}{|c|}{$\begin{array}{l}\text { Monitorowanie statusu neurologicznego } \\
\text { [10035326] }\end{array}$} & \\
\hline & \multicolumn{4}{|c|}{$\begin{array}{l}\text { Ocenianie statusu neurologicznego } \\
{[10036772]}\end{array}$} & \\
\hline & \multicolumn{4}{|c|}{ Terapia walidacyjna [10039382] } & \\
\hline & \multicolumn{4}{|c|}{ Towarzyszenie pacjentowi [10042613] } & \\
\hline
\end{tabular}




\begin{tabular}{|c|c|c|}
\hline $\begin{array}{c}\text { Wynik: } \\
\text { Diagnoza } \\
\text { pozytywna }\end{array}$ & $\begin{array}{l}\text { Efektywna percepcja sensoryczna [10028173] } \\
\text { Zmniejszający się niepokój [10027858] } \\
\text { Nastąpiła częściowa poprawa poczucia } \\
\text { świadomości pacjenta. Chory w dalszym ciągu } \\
\text { ma zaburzenia świadomości, jednak rzadziej i } \\
\text { nie odczuwa związanego } \\
\text { z nimi niepokoju }\end{array}$ & $\begin{array}{l}\text { walidacyjna } \\
\text { [10026644] }\end{array}$ \\
\hline
\end{tabular}

Tabela 13.

\begin{tabular}{|c|c|c|c|c|c|}
\hline Plan opieki & \multicolumn{4}{|c|}{$\begin{array}{l}\text { Osie wykorzystywane dla opisania } \\
\text { diagnozy pielęgniarskiej }\end{array}$} & \multirow{3}{*}{$\begin{array}{c}\text { Osie } \\
\text { wykorzystyw } \\
\text { ane do } \\
\text { opisania } \\
\text { interwencji }\end{array}$} \\
\hline $\begin{array}{l}\text { Nazwa osi } \\
\text { ICNP }\end{array}$ & $\begin{array}{l}\text { Diagnoza } \\
\text { (DC) }\end{array}$ & $\begin{array}{l}\text { Lokaliza } \\
\text { cja (L) }\end{array}$ & Czas (T) & $\begin{array}{l}\text { Klient } \\
\text { (C) }\end{array}$ & \\
\hline \multirow{2}{*}{$\begin{array}{c}\text { Diagnoza } \\
\text { pielęgniars } \\
\text { ka } \\
\text { nr } \mathbf{1 1} \\
\text { Niepokój } \\
\text { związany z } \\
\text { odrzuceniem } \\
\text { przeszczepio } \\
\text { nej wątroby i } \\
\text { strach przed } \\
\text { śmiercią }\end{array}$} & \multirow[t]{2}{*}{$\begin{array}{l}\text { Niepokój } \\
\text { przed } \\
\text { śmiercią } \\
{[1004101} \\
7]\end{array}$} & \multirow[t]{2}{*}{$\begin{array}{l}\text { Ciało } \\
{[1000338} \\
8]\end{array}$} & \multirow[t]{2}{*}{$\begin{array}{l}\text { Przyszłoś } \\
\text { ć } \\
{[1000829} \\
9]\end{array}$} & \multirow[t]{2}{*}{$\begin{array}{l}\text { Pacjent } \\
{[1001413} \\
2]\end{array}$} & \\
\hline & & & & & \multirow[t]{2}{*}{ Środki (M) } \\
\hline Cel opieki & \multicolumn{4}{|c|}{$\begin{array}{l}\text { Zmniejszenie poziomu nasilenia niepokoju, } \\
\text { poprawa nastroju pacjenta }\end{array}$} & \\
\hline \multirow{3}{*}{$\begin{array}{c}\text { Interwencje } \\
\text { pielęgniars } \\
\text { kie (IC) }\end{array}$} & \multicolumn{4}{|c|}{$\begin{array}{l}\text { Ocenianie statusu psychologicznego } \\
{[10030734]}\end{array}$} & \multirow{3}{*}{$\begin{array}{l}\text { Pielęgniarka } \\
\text { [10013333] } \\
\text { Narzędzie do } \\
\text { oceny } \\
\text { [10002832] }\end{array}$} \\
\hline & \multicolumn{4}{|c|}{ Ocenianie strachu [10024267] } & \\
\hline & \multicolumn{4}{|c|}{$\begin{array}{l}\text { Ocenianie agresywnego zachowania } \\
\text { [10035684] }\end{array}$} & \\
\hline
\end{tabular}




\begin{tabular}{|c|c|c|}
\hline & $\begin{array}{l}\text { Ocenianie postawy wobec choroby } \\
\text { [10024192] }\end{array}$ & $\begin{array}{l}\text { Technika } \\
\text { relaksacyjna }\end{array}$ \\
\hline & $\begin{array}{l}\text { Ocenianie akceptacji statusu zdrowia } \\
\text { [10026249] }\end{array}$ & $\begin{array}{l}{[10016700]} \\
\text { Terapia }\end{array}$ \\
\hline & Terapia relaksacyjna [10039191] & relaksacyjna \\
\hline & $\begin{array}{l}\text { Demonstrowanie technik relaksacyjnych } \\
\text { [10024365] }\end{array}$ & $\begin{array}{l}{[10039297]} \\
\text { Technika }\end{array}$ \\
\hline & Terapia odwracająca uwagę [10039348] & $\begin{array}{l}\text { uspokajania } \\
\text { [10003839] }\end{array}$ \\
\hline & Zarządzanie niepokojem [10031711] & Technika \\
\hline & $\begin{array}{l}\text { Wspieranie statusu psychologicznego } \\
\text { [10019161] }\end{array}$ & $\begin{array}{l}\text { odwracania } \\
\text { uwagi }\end{array}$ \\
\hline & $\begin{array}{l}\text { Zarządzanie zaburzonym procesem radzenia } \\
\text { sobie [10031846] }\end{array}$ & $\begin{array}{l}{[10006102]} \\
\text { Terapia }\end{array}$ \\
\hline & $\begin{array}{l}\text { Zapewnienie wsparcia emocjonalnego } \\
\text { [10027051] }\end{array}$ & $\begin{array}{l}\text { odwracająca } \\
\text { uwagę }\end{array}$ \\
\hline & Poradnictwo dotyczące strachu [10026208] & [10026637] \\
\hline & Nauczanie o chorobie [10024116] & \\
\hline $\begin{array}{l}\text { Wynik: } \\
\text { Diagnoza } \\
\text { pozytywna }\end{array}$ & $\begin{array}{l}\text { Zmniejszający się niepokój [10027858] } \\
\text { Pozytywny status psychologiczny } \\
\text { [10038430] } \\
\text { Pacjent lepiej rozumie swój stan zdrowia, } \\
\text { jego nastrój uległ poprawie, jednak należy } \\
\text { dalej obserwować chorego i rozmawiać z } \\
\text { nim na temat powyższego problemu }\end{array}$ & \\
\hline
\end{tabular}


Tabela 14.

\begin{tabular}{|c|c|c|c|c|c|}
\hline Plan opieki & \multicolumn{4}{|c|}{$\begin{array}{l}\text { Osie wykorzystywane dla opisania } \\
\text { diagnozy pielęgniarskiej }\end{array}$} & \multirow{3}{*}{$\begin{array}{c}\text { Osie } \\
\text { wykorzystyw } \\
\text { ane do } \\
\text { opisania } \\
\text { interwencji }\end{array}$} \\
\hline $\begin{array}{l}\text { Nazwa osi } \\
\text { ICNP }\end{array}$ & $\begin{array}{l}\text { Diagnoz } \\
\text { a (DC) }\end{array}$ & $\begin{array}{c}\text { Lokaliza } \\
\text { cja (L) }\end{array}$ & Czas (T) & $\begin{array}{l}\text { Klient } \\
\text { (C) }\end{array}$ & \\
\hline \multirow{2}{*}{$\begin{array}{c}\text { Diagnoza } \\
\text { pielęgniars } \\
\text { ka } \\
\text { nr } 12 \\
\text { Niepokój i } \\
\text { złe } \\
\text { samopoczuc } \\
\text { ie związane } \\
\text { z brakiem } \\
\text { wsparcia i } \\
\text { odwiedzin } \\
\text { rodziny }\end{array}$} & \multirow[t]{2}{*}{$\begin{array}{l}\text { Brak } \\
\text { wsparcia } \\
\text { rodziny } \\
{[100224} \\
73]\end{array}$} & \multirow[t]{2}{*}{$\begin{array}{l}\text { Ciało } \\
{[100033} \\
88]\end{array}$} & \multirow[t]{2}{*}{$\begin{array}{l}\text { Teraźniejsz } \\
\text { ość } \\
{[10015581]}\end{array}$} & \multirow[t]{2}{*}{$\begin{array}{l}\text { Pacjent } \\
{[100141} \\
32] \\
\text { Rodzina } \\
{[100075} \\
54]\end{array}$} & \\
\hline & & & & & \multirow[t]{2}{*}{ Środki (M) } \\
\hline Cel opieki & \multicolumn{4}{|c|}{$\begin{array}{l}\text { Zmniejszenie poziomu nasilenia niepokoju, } \\
\text { poprawa nastroju pacjenta, poprawa relacji } \\
\text { chorego z rodziną }\end{array}$} & \\
\hline \multirow{5}{*}{$\begin{array}{l}\text { Interwencj } \\
\text { e } \\
\text { pielęgniars } \\
\text { kie (IC) }\end{array}$} & \multicolumn{4}{|c|}{ Ocenianie nastroju depresyjnego [10026055] } & $\begin{array}{l}\text { Pielęgniarka } \\
\text { [10013333] } \\
\text { Terapeuta } \\
\text { zajęciowy } \\
\end{array}$ \\
\hline & \multicolumn{4}{|c|}{$\begin{array}{l}\text { Kierowanie na terapię w grupie wsparcia } \\
\text { [10024558] }\end{array}$} & $\begin{array}{l}\text { Narzędzie } \\
\text { do oceny }\end{array}$ \\
\hline & \multicolumn{4}{|c|}{ Nauczanie rodziny o chorobie [10021719] } & [10002832] \\
\hline & \multicolumn{4}{|c|}{$\begin{array}{l}\text { Nauczanie rodziny o zachowaniach } \\
\text { prozdrowotnych [10033119] }\end{array}$} & $\begin{array}{l}\text { Technika } \\
\text { relaksacyjna }\end{array}$ \\
\hline & \multicolumn{4}{|c|}{$\begin{array}{l}\text { Nauczanie rodziny o reżimie terapii } \\
{[10024656]}\end{array}$} & $\begin{array}{l}{[10016700]} \\
\text { Terapia }\end{array}$ \\
\hline
\end{tabular}




\begin{tabular}{|c|c|c|}
\hline & Nauczanie o procesie rodziny [10036153] & relaksacyjna \\
\hline & $\begin{array}{l}\text { Zapewnienie rodzinie wytycznych } \\
\text { dotyczących przyszłości [10026375] }\end{array}$ & $\begin{array}{l}{[10039297]} \\
\text { Technika }\end{array}$ \\
\hline & Promowanie pozytywnych relacji [10035759] & uspokajania \\
\hline & $\begin{array}{l}\text { Zapewnienie wsparcia emocjonalnego } \\
\text { [10027051] }\end{array}$ & \\
\hline & Terapia relaksacyjna [10039191] & \\
\hline & $\begin{array}{l}\text { Demonstrowanie technik relaksacyjnych } \\
\text { [10024365] }\end{array}$ & $\begin{array}{l}{[10006102]} \\
\text { Terapia }\end{array}$ \\
\hline & Terapia odwracająca uwagę [10039348] & odwracająca \\
\hline & Zarządzanie niepokojem [10031711] & $\begin{array}{l}\text { uwagę } \\
\text { [10026637] }\end{array}$ \\
\hline & $\begin{array}{l}\text { Wspieranie statusu psychologicznego } \\
\text { [10019161] }\end{array}$ & $\begin{array}{l}\text { Materiał } \\
\text { dydaktyczny }\end{array}$ \\
\hline $\begin{array}{l}\text { Wynik: } \\
\text { Diagnoza } \\
\text { pozytywna }\end{array}$ & $\begin{array}{l}\text { Efektywna odpowiedź na terapię [10036423] } \\
\text { Pozytywny status psychologiczny [10038430] } \\
\text { Pacjent zwraca mniej uwagi na powyższy } \\
\text { problem i odczuwa mniejszy niepokój z nim } \\
\text { związany, jednak rodzina dalej nie odwiedza } \\
\text { pacjenta i odmawia brania udziału w jego } \\
\text { leczeniu }\end{array}$ & [10011251] \\
\hline
\end{tabular}


Tabela 15.

\begin{tabular}{|c|c|c|c|c|c|}
\hline Plan opieki & Osie n & $\begin{array}{l}\text { ykorzysty } \\
\text { iagnozy pi }\end{array}$ & $\begin{array}{l}\text { wane dla opi } \\
\text { elęgniarskie }\end{array}$ & sania & \\
\hline $\begin{array}{l}\text { Nazwa osi } \\
\text { ICNP }\end{array}$ & $\begin{array}{l}\text { Diagnoza } \\
\text { (DC) }\end{array}$ & $\begin{array}{c}\text { Lokaliza } \\
\text { cja (L) }\end{array}$ & Czas (T) & $\begin{array}{l}\text { Klient } \\
\text { (C) }\end{array}$ & $\begin{array}{l}\text { Osie } \\
\text { wykorzystyw }\end{array}$ \\
\hline $\begin{array}{c}\text { Diagnoza } \\
\text { pielęgniars } \\
\text { ka } \\
\text { nr } 13 \\
\text { Smutek i }\end{array}$ & $\begin{array}{l}\text { Smutek } \\
{[1004066} \\
2] \\
\text { (+termin } \\
\text { z osi F }\end{array}$ & $\begin{array}{l}\text { Ciało } \\
{[100033} \\
88]\end{array}$ & $\begin{array}{l}\text { Teraźniejsz } \\
\text { ość } \\
{[10015581} \\
{[}\end{array}$ & $\begin{array}{l}\text { Pacjent } \\
{[100141} \\
32]\end{array}$ & $\begin{array}{c}\text { ane do } \\
\text { opisania } \\
\text { interwencji }\end{array}$ \\
\hline $\begin{array}{c}\text { nıepoko] } \\
\text { związany z } \\
\text { samotności } \\
\text { ą i długim } \\
\text { pobytem w } \\
\text { szpitalu }\end{array}$ & $\begin{array}{l}\text { samotnos } \\
\text { ć } \\
{[1001141} \\
7])\end{array}$ & & & & Środki (M) \\
\hline Cel opieki & \multicolumn{4}{|c|}{$\begin{array}{l}\text { Zmniejszenie poziomu smutku i niepokoju, } \\
\text { poprawa samopoczucia pacjenta }\end{array}$} & \\
\hline \multirow{9}{*}{$\begin{array}{l}\text { Interwencj } \\
\text { e } \\
\text { pielęgniars } \\
\text { kie (IC) }\end{array}$} & \multicolumn{4}{|c|}{ Ocenianie nastroju depresyjnego [10026055] } & \multirow{9}{*}{$\begin{array}{l}\text { Pielęgniarka } \\
{[10013333]} \\
\text { Terapeuta } \\
\text { zajęciowy } \\
\text { [10026628] } \\
\text { Narzędzie } \\
\text { do oceny } \\
\text { [10002832] } \\
\text { Technika } \\
\text { relaksacyjna } \\
\text { [10016700] } \\
\text { Terapia } \\
\text { relaksacyjna } \\
\text { [10039297] }\end{array}$} \\
\hline & \multicolumn{4}{|c|}{ Ocenianie niepokoju [10041745] } & \\
\hline & \multicolumn{4}{|c|}{$\begin{array}{l}\text { Ocenianie poczucia własnej wartości } \\
{[10027079]}\end{array}$} & \\
\hline & \multicolumn{4}{|c|}{$\begin{array}{l}\text { Ocenianie postawy wobec choroby } \\
\text { [10024192] }\end{array}$} & \\
\hline & \multicolumn{4}{|c|}{$\begin{array}{l}\text { Ocenianie potrzeb dotyczących opieki } \\
\text { zdrowotnej i opieki społecznej [10030618] }\end{array}$} & \\
\hline & \multicolumn{4}{|c|}{ Ocenianie poziomu stresu [10043809] } & \\
\hline & \multicolumn{4}{|c|}{ Ocenianie smutku [10038940] } & \\
\hline & \multicolumn{4}{|c|}{$\begin{array}{l}\text { Ocenianie statusu psychologicznego } \\
{[10030734]}\end{array}$} & \\
\hline & \multicolumn{4}{|c|}{ Terapia relaksacyjna [10039191] } & \\
\hline
\end{tabular}




\begin{tabular}{|c|c|c|}
\hline & $\begin{array}{l}\text { Demonstrowanie technik relaksacyjnych } \\
\text { [10024365] }\end{array}$ & \multirow{9}{*}{$\begin{array}{l}\text { Technika } \\
\text { wywiad } \\
\text { motywujący } \\
\text { [10038634] } \\
\text { Technika } \\
\text { zarządzania } \\
\text { stresem } \\
\text { [10038675] }\end{array}$} \\
\hline & $\begin{array}{l}\text { Wspieranie statusu psychologicznego } \\
\text { [10019161] }\end{array}$ & \\
\hline & Zarządzanie niepokojem [10031711] & \\
\hline & $\begin{array}{l}\text { Zarządzanie zaburzonym procesem radzenia } \\
\text { sobie [10031846] }\end{array}$ & \\
\hline & $\begin{array}{l}\text { Promowanie pozytywnego statusu } \\
\text { psychologicznego [10032505] }\end{array}$ & \\
\hline & $\begin{array}{l}\text { Zapewnienie wsparcia emocjonalnego } \\
\text { [10027051] }\end{array}$ & \\
\hline & Promowanie nadziei [10024440] & \\
\hline & $\begin{array}{l}\text { Kierowanie na terapię w grupie wsparcia } \\
\text { [10024558] }\end{array}$ & \\
\hline $\begin{array}{c}\text { Wynik: } \\
\text { Diagnoza } \\
\text { pozytywna }\end{array}$ & $\begin{array}{l}\text { Pozytywny status psychologiczny [10038430] } \\
\text { Pacjent zaczyna nawiązywać kontakt z innymi } \\
\text { pacjentami, nastąpiła poprawa jego nastroju i } \\
\text { został zmniejszony poziom smutku i } \\
\text { niepokoju }\end{array}$ & \\
\hline
\end{tabular}

Tabela 16.

\begin{tabular}{|c|c|c|c|c|c|}
\hline Plan opieki & \multicolumn{4}{|c|}{$\begin{array}{l}\text { Osie wykorzystywane dla opisania } \\
\text { diagnozy pielęgniarskiej }\end{array}$} & \multirow{3}{*}{$\begin{array}{c}\text { Osie } \\
\text { wykorzystyw } \\
\text { ane do } \\
\text { opisania } \\
\text { interwencji }\end{array}$} \\
\hline $\begin{array}{l}\text { Nazwa osi } \\
\text { ICNP }\end{array}$ & $\begin{array}{l}\text { Diagnoz } \\
\text { a (DC) }\end{array}$ & $\begin{array}{c}\text { Lokaliza } \\
\text { cja (L) }\end{array}$ & Czas (T) & $\begin{array}{l}\text { Klient } \\
\text { (C) }\end{array}$ & \\
\hline $\begin{array}{c}\text { Diagnoza } \\
\text { pielęgniars } \\
\text { ka } \\
\text { nr } 14\end{array}$ & \multirow{2}{*}{$\begin{array}{l}\text { Deficyt } \\
\text { samoopie } \\
\text { ki } \\
{[100234} \\
10]\end{array}$} & \multirow[t]{2}{*}{$\begin{array}{l}\text { Ciało } \\
{[100033} \\
88]\end{array}$} & \multirow[t]{2}{*}{$\begin{array}{l}\text { Teraźniejsz } \\
\text { ość } \\
{[10015581]}\end{array}$} & \multirow[t]{2}{*}{$\begin{array}{l}\text { Pacjent } \\
{[100141} \\
32]\end{array}$} & \\
\hline $\begin{array}{l}\text { Deficyt } \\
\text { samoopieki }\end{array}$ & & & & & Środki (M) \\
\hline
\end{tabular}




\begin{tabular}{|c|c|c|}
\hline Cel opieki & $\begin{array}{l}\text { Zwiększenie poziomu samodzielności i } \\
\text { zdolności do samoopieki pacjenta }\end{array}$ & \\
\hline \multirow{9}{*}{$\begin{array}{c}\text { Interwencj } \\
\text { e } \\
\text { pielęgniars } \\
\text { kie (IC) }\end{array}$} & Ocenianie samoopieki [10021844] & \multirow{10}{*}{$\begin{array}{l}\text { Pielęgniarka } \\
\text { [10013333] } \\
\text { Narzędzie do } \\
\text { oceny } \\
\text { [10002832] } \\
\text { Urządzenia do } \\
\text { dbania o } \\
\text { siebie } \\
\text { [10008537] } \\
\text { Technika } \\
\text { wywiad } \\
\text { motywujący } \\
\text { [10038634] }\end{array}$} \\
\hline & Ewaluacja planu opieki [10031252] & \\
\hline & Instruowanie pacjenta [10010382] & \\
\hline & Wzmacnianie samodzielności [10022537] & \\
\hline & $\begin{array}{l}\text { Dostarczenie wsparcia społecznego } \\
{[10027046]}\end{array}$ & \\
\hline & Nauczanie o reżimie terapii [10024625] & \\
\hline & Nauczanie o samoopiece [10045014] & \\
\hline & Asystowanie w samoopiece [10035763] & \\
\hline & Promowanie samoopieki [10026347] & \\
\hline $\begin{array}{c}\text { Wynik: } \\
\text { Diagnoza } \\
\text { pozytywna }\end{array}$ & $\begin{array}{l}\text { Zdolny do samoopieki [10025714] } \\
\text { Wzrósł poziom samodzielności pacjenta. } \\
\text { Chory samodzielnie spożywa posiłki, } \\
\text { częściowo zmienia ubranie i porusza się w } \\
\text { obrębie sali, potrzebuje pomocy przy } \\
\text { czynnościach higienicznych i toalecie. Pacjent } \\
\text { otrzymał } 15 \text { punktów w skali Lewton (IADL) i } \\
60 \text { punktów w skali Barthel (PADL), co } \\
\text { wskazuje, że stan pacjenta jest średnio ciężki }\end{array}$ & \\
\hline
\end{tabular}

Tabela 17.

\begin{tabular}{|c|c|c|c|c|c|}
\hline Plan opieki & \multicolumn{4}{|c|}{$\begin{array}{c}\text { Osie wykorzystywane dla opisania } \\
\text { diagnozy pielęgniarskiej }\end{array}$} & \multirow{3}{*}{$\begin{array}{c}\text { Osie } \\
\text { wykorzystyw } \\
\text { ane do } \\
\text { opisania } \\
\text { interwencji }\end{array}$} \\
\hline $\begin{array}{l}\text { Nazwa osi } \\
\text { ICNP }\end{array}$ & $\begin{array}{l}\text { Diagnoz } \\
\text { a (DC) }\end{array}$ & $\begin{array}{c}\text { Lokaliza } \\
\text { cja (L) }\end{array}$ & Czas (T) & $\begin{array}{l}\text { Klient } \\
\text { (C) }\end{array}$ & \\
\hline Diagnoza & Brak & Ciało & Teraźniejsz & Pacjent & \\
\hline
\end{tabular}




\begin{tabular}{|c|c|c|c|c|c|}
\hline Innowacje & elęgnic & ie i $N$ & 0 & & $4(4) / 2019$ \\
\hline $\begin{array}{c}\text { pielęgniars } \\
\text { ka } \\
\text { nr 15 } \\
\text { Deficyt } \\
\text { wiedzy } \\
\text { pacjenta na } \\
\text { temat } \\
\text { choroby i } \\
\text { leczenia }\end{array}$ & $\begin{array}{l}\text { wiedzy o } \\
\text { chorobie } \\
{[100219} \\
94]\end{array}$ & $\begin{array}{l}{[100033} \\
88]\end{array}$ & $\begin{array}{l}\text { ość } \\
{[10015581]}\end{array}$ & $\begin{array}{l}{[100141} \\
32]\end{array}$ & \multirow[t]{2}{*}{ Środki (M) } \\
\hline Cel opieki & \multicolumn{4}{|c|}{$\begin{array}{l}\text { Poprawa stanu wiedzy pacjenta na temat } \\
\text { choroby i leczenia }\end{array}$} & \\
\hline \multirow{7}{*}{$\begin{array}{l}\text { Interwencj } \\
\text { e } \\
\text { pielęgniars } \\
\text { kie (IC) }\end{array}$} & \multicolumn{4}{|c|}{ Nauczanie o chorobie [10024116] } & \multirow{9}{*}{\begin{tabular}{|l|} 
Pielęgniarka \\
{$[10013333]$} \\
Narzędzie \\
do oceny \\
{$[10002832]$} \\
Materiał \\
dydaktyczny \\
{$[10011251]$} \\
Usługa \\
edukacji \\
zdrowotnej \\
{$[10039459]$}
\end{tabular}} \\
\hline & \multicolumn{4}{|c|}{$\begin{array}{l}\text { Nauczanie o kontrolowaniu objawów } \\
\text { podmiotowych [10038080] }\end{array}$} & \\
\hline & \multicolumn{4}{|c|}{ Nauczanie o odżywianiu [10024618] } & \\
\hline & \multicolumn{4}{|c|}{$\begin{array}{l}\text { Nauczanie o zachowaniach prozdrowotnych } \\
\text { [10032956] }\end{array}$} & \\
\hline & \multicolumn{4}{|c|}{ Ocenianie wiedzy o chorobie [10030639] } & \\
\hline & \multicolumn{4}{|c|}{$\begin{array}{l}\text { Promowanie zachowań prozdrowotnych } \\
\text { [10032465] }\end{array}$} & \\
\hline & \multicolumn{4}{|c|}{$\begin{array}{l}\text { Zapewnienie materiału instruktażowego } \\
\text { [10024493] }\end{array}$} & \\
\hline Wynik: & \multirow{2}{*}{\multicolumn{4}{|c|}{$\begin{array}{l}\text { Wiedza adekwatna [10027112] } \\
\text { Pacjent ma większą wiedzę na temat swojej } \\
\text { choroby i leczenia }\end{array}$}} & \\
\hline $\begin{array}{l}\text { Diagnoza } \\
\text { pozytywna }\end{array}$ & & & & & \\
\hline
\end{tabular}


Tabela 18.

\begin{tabular}{|c|c|c|c|c|c|}
\hline Plan opieki & Osie & $\begin{array}{l}\text { vykorzyst } \\
\text { liagnozy p }\end{array}$ & $\begin{array}{l}\text { wane dla opi } \\
\text { ielęgniarskie }\end{array}$ & sania & \multirow{3}{*}{$\begin{array}{c}\text { Osie } \\
\text { wykorzystyw } \\
\text { ane do } \\
\text { opisania } \\
\text { interwencji }\end{array}$} \\
\hline $\begin{array}{l}\text { Nazwa osi } \\
\text { ICNP }\end{array}$ & $\begin{array}{l}\text { Diagnoz } \\
\text { a (DC) }\end{array}$ & $\begin{array}{l}\text { Lokaliza } \\
\text { cja (L) }\end{array}$ & $\operatorname{Czas}(\mathrm{T})$ & $\begin{array}{l}\text { Klient } \\
\text { (C) }\end{array}$ & \\
\hline $\begin{array}{c}\text { Diagnoza } \\
\text { pielęgniars } \\
\text { ka } \\
\text { nr } 16 \\
\text { Zagrożenie }\end{array}$ & \multirow[t]{2}{*}{$\begin{array}{l}\text { Agresyw } \\
\text { ne } \\
\text { zachowa } \\
\text { nie } \\
{[100354} \\
80]\end{array}$} & \multirow[t]{2}{*}{$\begin{array}{l}\text { Ciało } \\
{[100033} \\
88]\end{array}$} & \multirow[t]{2}{*}{$\begin{array}{l}\text { Teraźniejsz } \\
\text { ość } \\
{[10015581]}\end{array}$} & \multirow[t]{2}{*}{$\begin{array}{l}\text { Pacjent } \\
{[100141} \\
32]\end{array}$} & \\
\hline $\begin{array}{c}\text { uszczerbku } \\
\text { na zdrowiu } \\
\text { pacjenta, } \\
\text { innych } \\
\text { pacjentów i } \\
\text { personelu } \\
\text { stwarzane } \\
\text { przez } \\
\text { agresywny } \\
\text { m } \\
\text { zachowanie } \\
\text { pacjenta }\end{array}$ & & & & & \multirow[t]{2}{*}{ Środki (M) } \\
\hline Cel opieki & \multicolumn{4}{|c|}{$\begin{array}{l}\text { Zniwelowanie zagrożenia stwarzanego przez } \\
\text { pacjenta }\end{array}$} & \\
\hline \multirow{5}{*}{$\begin{array}{l}\text { Interwencj } \\
\text { e } \\
\text { pielęgniars } \\
\text { kie (IC) }\end{array}$} & \multicolumn{4}{|c|}{$\begin{array}{l}\text { Ocenianie agresywnego zachowania } \\
{[10035684]}\end{array}$} & \multirow{5}{*}{$\begin{array}{l}\text { Pielęgniarka } \\
{[10013333]} \\
\text { Terapeuta } \\
\text { zajęciowy } \\
\text { [10026628] } \\
\text { Narzędzie } \\
\text { do oceny } \\
\text { [10002832] }\end{array}$} \\
\hline & \multicolumn{4}{|c|}{$\begin{array}{l}\text { Ocenianie statusu psychologicznego } \\
{[10030734]}\end{array}$} & \\
\hline & \multicolumn{4}{|c|}{ Administrowanie lekiem [10025444] } & \\
\hline & \multicolumn{4}{|c|}{$\begin{array}{l}\text { Zarządzanie aktywnością pacjenta } \\
\text { [10044971] }\end{array}$} & \\
\hline & \multicolumn{4}{|c|}{ Zarządzanie bezpieczeństwem środowiska } & \\
\hline
\end{tabular}




\begin{tabular}{|c|c|c|}
\hline & {$[10042507]$} & \\
\hline & Terapia relaksacyjna [10039191] & \\
\hline & $\begin{array}{l}\text { Demonstrowanie technik relaksacyjnych } \\
\text { [10024365] }\end{array}$ & relaksacyjna \\
\hline & Zarządzanie nastrojem [10036256] & Terapia \\
\hline & $\begin{array}{l}\text { Zarządzanie negatywnym zachowaniem } \\
\text { [10031833] }\end{array}$ & $\begin{array}{l}\text { relaksacyjna } \\
{[10039297]}\end{array}$ \\
\hline & $\begin{array}{l}\text { Zarządzanie negatywnymi emocjami } \\
\text { [10031851] }\end{array}$ & \\
\hline & $\begin{array}{l}\text { Zarządzanie zachowaniem agresywnym } \\
\text { [10035970] }\end{array}$ & \\
\hline & $\begin{array}{l}\text { Kierowanie na terapię w grupie wsparcia } \\
\text { [10024558] }\end{array}$ & \\
\hline & $\begin{array}{l}\text { Zapewnienie wsparcia emocjonalnego } \\
\text { [10027051] }\end{array}$ & \\
\hline $\begin{array}{c}\text { Wynik: } \\
\text { Diagnoza } \\
\text { pozytywna }\end{array}$ & $\begin{array}{l}\text { Bez zachowań agresywnych [10035645] } \\
\text { Zapewniono bezpieczeństwo pacjentowi i } \\
\text { otoczeniu. Pacjent jest pod ciągłą obserwacją } \\
\text { personelu oraz ma zapewniony dostęp do żył } \\
\text { obwodowych przez kaniule w celu szybkiego } \\
\text { podania leków uspokajających w razie } \\
\text { potrzeby }\end{array}$ & \\
\hline
\end{tabular}

\section{Dyskusja}

Decyzję o zakwalifikowaniu pacjenta do ponownej transplantacji podejmuje lekarz na podstawie wskazań i przeciwwskazań do przeszczepienia wątroby, zasad alokacji i dystrybucji wątroby [11]. Ważne jest poznanie genezy przedwczesnego odrzucania przeszczepionego narządu i szczegółowy wywiad $\mathrm{z}$ pacjentem na ten temat. Przeciwwskazaniami do transplantacji wątroby zależnymi od woli pacjenta są: aktywne uzależnienie od alkoholu i substancji odurzających oraz bezdomność 
brak ubezpieczenia, natomiast głównym z nich jest brak współpracy $\mathrm{z}$ chorym i jego niestosowanie się do zaleceń personelu medycznego $[4,11]$.

Pielęgniarka, opiekując się pacjentem, który nie zostaje zakwalifikowany do ponownej transplantacji, i w związku z czym którego rokowanie co do jego szans przeżycia jest niekorzystne, powinna pomóc mu zrozumieć istotę jego choroby i jego obecny stan zdrowia, oraz wspierać go w radzeniu sobie z jej konsekwencjami. Zwykle chory potrzebuje również asystowania i pomocy w czynnościach życia codziennego, zwłaszcza w chodzeniu, toalecie i czynnościach higienicznych, a także w sferze psychicznej.

Jednym z problemów pielęgnacyjnych u opisywanego pacjenta było ryzyko pogłębienia się uciążliwych objawów encefalopatii wątrobowej, czyli zaburzenie funkcjonowania centralnego układu nerwowego na skutek działania toksyn [12]. W tej sytuacji ważna była całodobowa obserwacja pielęgniarska i monitorowanie stanu świadomości, co pozwoliło na podjęcie właściwych działań w krótkim czasie.

Kolejnym ważnym problemem pielęgnacyjnym u opisywanego pacjenta był brak współpracy i odmowa przyjmowania leków immunosupresyjnych. Należy zaznaczyć, że głównym celem leczenia immunosupresyjnego jest wytworzenie tolerancji immunologicznej na przeszczepiony narząd [12]. Nieregularne przyjmowanie leków immunosupresyjnych najczęściej kończy się ostrym odrzucaniem komórkowym, ale mogą też wystąpić inne powikłania [14]. Niestosowanie się opisywanego pacjenta do zaleceń lekarskich w zakresie przyjmowania leków immunosupresyjnych wynikało pośrednio z nieznajomości własnej jednostki chorobowej i niedostatecznej wiedzy na temat własnego stanu zdrowia. U chorego zaplanowano, a następnie przeprowadzono rozmowę edukacyjną, po której uzyskano z nim częściową współpracę. 
Opisywany pacjent miał zwiększone ryzyko upadków bowiem w skali oceny ryzyka upadków Tinetti uzyskał 18 punktów. Pacjent swobodnie poruszał się $\mathrm{w}$ obrębie sali przy pomocy balkonika lub laski inwalidzkiej. W skali Tinetti ocenie podlegają czynności takie jak: równowaga $\mathrm{w}$ pozycji siedzącej, wstawanie $\mathrm{z}$ krzesła, równowaga zaraz po wstaniu i podczas stania, próba trącania przy otwartych i zamkniętych oczach, obrót o $360^{\circ}$ oraz siadanie; w jaki sposób pacjent rozpoczyna chód, jak wygląda długość i wysokość kroku, a także jego symetria, jak wygląda ścieżka chodu, jak wygląda praca tułowia i w jaki sposób pacjent ustawia stopy podczas chodu. Wynik $<26$ punktów oznacza ryzyko upadku, a <19 punktów 5-krotnie wyższe ryzyko upadku niż osoba niezagrożona ryzykiem upadku. [15]. Ryzyko upadku u opisywanego chorego zostało zminimalizowane poprzez zapewnienie mu bezpieczeństwa podczas poruszania się.

Kolejnym objawem stwierdzonym u pacjenta był ból. Zastosowano numeryczną skalę oceny bólu NRS, mierząc jego nasilenie od 0 do 10, gdzie 0 oznacza całkowity brak bólu, natomiast 10 najgorszy wyobrażalny ból. [16] Pacjent ocenił swój ból na 5, co oznacza ból średni. Podano leki przeciwbólowe na zlecenie lekarza, monitorowano parametry życiowe i przeprowadzono ocenę bólu po podaniu leku w celu oceny ich skuteczności.

Wiele problemów pielęgnacyjnych zdiagnozowanych u pacjenta dotyczyły dotyczące stanu psychospołecznego. Terapia reminiscencyjna według Andrew Norrisa to terapia przez przywoływanie wspomnień $\mathrm{z}$ najważniejszych doświadczeń osobistych, wykorzystująca fotografie, pamiętniki, stare przedmioty. [17] Zastosowano ją jako rozwiązanie problemu niepokoju pacjenta, dzięki czemu uzyskano jego zmniejszenie. Natomiast rozmowy edukacyjne $\mathrm{z}$ pacjentem, techniki relaksacyjne i odwracania uwagi pozwoliły poprawić obniżone samopoczucie pacjenta spowodowane 
niepokojem związany $\mathrm{z}$ odrzuceniem przeszczepionej wątroby, strachem przed śmiercią, brakiem wsparcia i odwiedzin rodziny, samotnością i długim pobytem w szpitalu. Nie udało się uzyskać wsparcia od rodziny pacjenta i namówić ich do odwiedzin.

Jak wspomniano powyżej, plan opieki nad opisywanym pacjentem został sformułowany w oparciu o teorię Virginii Henderson [9]. W opiece uwzględniono holistyczne podejście do pacjenta obejmujące zaspokojenie jego potrzeb fizjologicznych, psychologicznych i duchowy. Pielęgniarka, która wdrażała ten plan, na bieżąco oceniała wyniki swojej pracy. Wykonane interwencje mające na celu realizację planu, pozytywnie wpłynęły na jakość życia pacjenta.

\section{Wnioski}

Świadomość przewlekłej choroby, która nie może zostać wyleczona jest trudna zarówno dla personelu medycznego jak i samego pacjenta. Opieka pielęgniarska $\mathrm{w}$ takim przypadku powinna skupiać się na poprawie aktualnej jakości i zapewnieniu maksymalnego komfortu życia oraz zaspokajaniu codziennych potrzeb chorego. Pielęgniarka zapewnia także warunki godnej, spokojnej śmierci. Jej rolą jest również wsparcie psychologiczne zarówno samego pacjenta jak i jego rodziny.

Zastosowanie Międzynarodowej Klasyfikacji Praktyki Pielęgniarskiej ICNP® w planowaniu opieki pielęgniarskiej nad pacjentem $\mathrm{z}$ niewydolnością wątroby przeszczepionej pozwala na ulepszenie działań pielęgniarskich o nowoczesną metodę ujednolicenia systemu komunikowania się w pielęgniarstwie, dzięki czemu wiedza o opiece nad pacjentem jest łatwiej dostępna i zrozumiała na obszarze międzynarodowym. 


\section{Bibliografia/Bibliography:}

1. Farkas S., Hackl C., Schlitt H. J. Overview of the indications and contraindications for liver transplantation. Cold Spring Harb. Perspect. Med. 2014;4(5):1-13.

2. Czarkowska-Pączek, B., Wesołowska-Górniak K., Wójtowicz, M. Aktywność zawodowa pacjentów po przeszczepie nerki lub wątroby. Niepełnosprawność - zagadnienia, problemy, rozwiązania. 2018;3 (28):7-24.

3. Ferreira R., Júnior M., Salvalaggio P., Bruno de Rezende M., Evangelista A. S., Guardia B. D., Matielo C. E. L., Neves D. B., Pandullo F. L., Felga G.E.G. da Silva Alves J. A., Lilian L. A., Diaz L. G. G., Rusi M. B., de Melo Viveiros M., de Almeida M. D., Pedroso P. T., Rocco R. A., Filho1et S. P. M. Liver transplantation: history, outcomes and perspectives. Einstein. 2015;13(1):149-52.

4. Rodrigue J. R., Nelson D. R., Hanto D. W., Reed A. I.,Curry M. P.Patientreported immunosuppression nonadherence 6 to 24 months after liver transplant: association with pretransplant psychosocial factors and perceptions of health status change. Prog Transplant. 2013;23(4):319 328

5. Hreńczuk M., Małkowski P. Pacjent z zespołem wątrobowo-nerkowym zadania pielęgniarki $\mathrm{w}$ transplantacji wątroby Patient with hepatorenal syndrome - nursing care in liver transplantation. Forum Nefrologiczne. 2015;8(3):193-198.

6. Finn L., Malhotra S. The Development of Pathways in Palliative Medicine: Definition, Models, Cost and Quality Impact. Healthcare. 2019;7(22):1-10.

7. Kimbell B, Murray S. A., Byrne H., Baird A., Hayes P. C., MacGilchrist A. Finucane A., Young P. B., O'Carroll R. E., Weir Ch. J, Kendall M. Boyd K. Palliative care for people with advanced liver disease: A feasibility trial of a supportive care liver nurse specialist. Palliative Medicine. 
2018;32(5):919-929.

8. International Council of Nurses. International Classification for Nursing Practice Version 1. Geneva: The Association; 2005.

9. Henderson, V. The Nature of Nursing: A Definition and its Implications for Practice, Research, and Education. New York: Macmillan Publishing; 1966.

10.Zarzycka D. Model teoretyczny pielęgniarstwa Virginii Henderson [w:] Ślusarska B., Zarzycka D., Zahradniczek K. (Red.), Podstwy pielęgniarstwa tom I założenia teoretyczne. PZWL, Lublin 2013;183-196.

11. Poltransplant (2019) Zasady dystrybucji i alokacji narządów: narządówhttps://www.poltransplant.org.pl/alokacja2.html\#watroba010 72018 [viewed: 04.12.2019].

12. Habior A. Ostra niewydolność wątroby. Postępy Nauk Medycznych. 2014;27(1).

13. Polskie Towarzystwo Transplantacyjne, Zalecenia dotyczące leczenia immunosupresyjnego po przeszczepieniu narządów unaczynionych, 2016: 1-164.

14. Heleniak Z., Chamienia A., Postępy w transplantologii nerki i wątroby nowe pytania, nowe możliwości, Forum Nefrologiczne, 2017; 10: 1-14.

15. Borowicz A. M., Wieczorowska-Tobis K. Ocena ryzyka upadku u osób starszych przebywających na oddziale rehabilitacyjnym The assessment of the risk of falls in elderly subjects on rehabilitation ward. Geriatria. 2011;5:13-18.

16. Kocot-Kępska M., Szułdrzyński K. Skale oceny bólu. Medycyna Praktyczna. 2014. 
17. Baumann K. Muzykoterapia i reminiscencja jako szansa rozwoju w okresie późnej dorosłości. Music therapy and reminiscence as a chance of development in old age. Gerontologia Polska. 2005;13(3):170-176.

Otrzymano: 13.03.2019r.

Zaakceptowano: $21.04 .2019 \mathrm{r}$.

38100 znaków 